\title{
Air quality in North America's most populous city - overview of the MCMA-2003 campaign
}

\author{
L. T. Molina ${ }^{1,2}$, C. E. Kolb ${ }^{3}$, B. de Foy ${ }^{1,2,4}$, B. K. Lamb ${ }^{5}$, W. H. Brune ${ }^{6}$, J. L. Jimenez ${ }^{7,8}$, R. Ramos-Villegas ${ }^{9}$, \\ J. Sarmiento ${ }^{9}$, V. H. Paramo-Figueroa ${ }^{9}$, B. Cardenas $^{10}$, V. Gutierrez-Avedoy ${ }^{10}$, and M. J. Molina ${ }^{1,11}$ \\ ${ }^{1}$ Department of Earth, Atmospheric and Planetary Science, Massachusetts Institute of Technology, Cambridge, MA, USA \\ ${ }^{2}$ Molina Center for Energy and Environment, La Jolla, CA, USA \\ ${ }^{3}$ Aerodyne Research, Inc., Billerica, MA, USA \\ ${ }^{4}$ Saint Louis University, St. Louis, MO, USA \\ ${ }^{5}$ Laboratory for Atmospheric Research, Department of Civil and Environmental Engineering, Washington State University, \\ Pullman, WA, USA \\ ${ }^{6}$ Department of Meteorology, Pennsylvania State University, University Park, PA, USA \\ ${ }^{7}$ Department of Chemistry and Biochemistry, University of Colorado at Boulder, Boulder, CO, USA \\ ${ }^{8}$ Cooperative Institute for Research in the Environmental Sciences (CIRES), Univ. of Colorado at Boulder, Boulder, CO, USA \\ ${ }^{9}$ Secretary of Environment, Government of the Federal District, Mexico, DF, Mexico \\ ${ }^{10}$ National Center for Environmental Research and Training, National Institute of Ecology, Mexico, DF, Mexico \\ ${ }^{11}$ Department of Chemistry and Biochemistry, University of California at San Diego, San Diego, CA, USA
}

Received: 22 February 2007 - Published in Atmos. Chem. Phys. Discuss.: 27 February 2007

Revised: 10 May 2007 - Accepted: 10 May 2007 - Published: 14 May 2007

\begin{abstract}
Exploratory field measurements in the Mexico City Metropolitan Area (MCMA) in February 2002 set the stage for a major air quality field measurement campaign in the spring of 2003 (MCMA-2003). Involving over 100 scientists from more than 30 institutions in Mexico, the United States and Europe, MCMA-2003 revealed important new insights into the meteorology, primary pollutant emissions, ambient secondary pollutant precursor concentrations, photochemical oxidant production and secondary aerosol particle formation in North America's most populated and polluted megacity. A description of meteorological and atmospheric chemistry and aerosol microphysics measurements performed during MCMA-2003 is presented. More than 40 published or submitted MCMA-2003 research papers are reviewed and key discoveries pertinent to understanding and improving air quality in Mexico City and similar megacities in the developing world are summarized.
\end{abstract}

Correspondence to: L. T. Molina

(1tmolina@mit.edu)

\section{Introduction}

\subsection{Air pollution in megacities}

Degraded air quality in an increasingly urbanized world directly threatens the health of a large fraction of the world's population, impacts the viability of important natural and agricultural ecosystems in regions surrounding highly urbanized areas, and contributes significantly to regional and global climate change. This challenge is particularly acute in the developing world where the rapid growth of megacities is producing atmospheric pollution of unprecedented severity and extent. There is growing recognition that airborne emissions from major urban and industrial areas influence both air quality and climate change on scales ranging from regional up to continental and global (Decker et al., 2000; Mayer et al., 2000; Molina and Molina, 2004; Molina et al., 2004).

Urban/industrial emissions from the developed world, and increasingly from the megacities (urban centers with population over 10 millions) of the developing world, change the chemical content of the downwind troposphere in a number of fundamental ways (Molina et al., 2004). Emissions of nitrogen oxides $\left(\mathrm{NO}_{\mathrm{x}}\right), \mathrm{CO}$ and volatile organic compounds

Published by Copernicus Publications on behalf of the European Geosciences Union. 


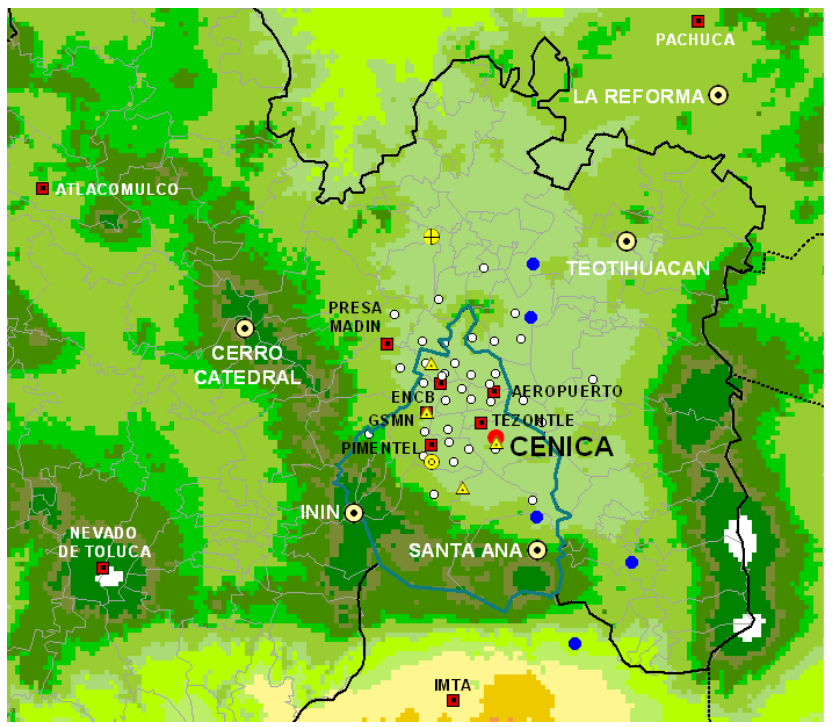

Fig. 1. Topographical map of the MCMA showing the monitoring sites during MCMA 2002/2003 campaign: 36 RAMA stations (o), SMA EHCA stations (回), CCA-UNAM network ( ), boundary sites $(\odot)$, SODAR $(\odot)$, pilot balloon locations $(\triangle)$, tethered balloon $(\oplus)$, CENICA (๑) (Fig. by M. Zavala.).

(VOCs) drive the formation of photochemical smog and its associated oxidants, degrading air quality and threatening both human and ecosystem health. On a larger scale, these same emissions drive the production of ozone (a powerful greenhouse gas) in the free troposphere, contributing significantly to global warming. Urban and industrial areas are also major sources of the directly forcing greenhouse gases, including $\mathrm{CO}_{2}, \mathrm{CH}_{4}, \mathrm{~N}_{2} \mathrm{O}$ and halocarbons. Nitrogen oxide and sulfur oxide emissions are processed to strong acids by atmospheric photochemistry on regional to continental scales, driving acid deposition to sensitive ecosystems. Direct urban/industrial emissions of carbonaceous aerosol particles are compounded by the emission of high levels of secondary aerosol precursors, including: $\mathrm{NO}_{\mathrm{x}}, \mathrm{VOCs}, \mathrm{SO}_{2}$, and $\mathrm{NH}_{3}$, resulting in the production of copious amounts of fine aerosol, affecting air quality in the urban source areas, the local radiation balance, and cloud formation hundreds to thousands of kilometers downwind.

Recently, a benchmark study of air quality in the Mexico City Metropolitan Area (MCMA), a rapidly growing megacity with a current population of approximately 20 million, was undertaken by a team of U.S., European and Mexican scientists and engineers under the leadership of L. T. Molina and M. J. Molina. The Mexico City Project, focused on North America's most populous urban area, was planned as a case study of the Integrated Program on Urban, Regional and Global Air Pollution - a collaborative research and education program initiated at the Massachusetts Institute of Technology (MIT) by L. T. Molina and M. J. Molina in 1999 to address the air pollution problems of megacities in a co- ordinated and interdisciplinary manner. The Mexico City Project included active collaboration with Mexican government officials and decision makers. Although the initial focus of the Integrated Program was on the MCMA, its goal was to develop methods of integrated assessment applicable to other large urban centers throughout the world (Molina and Molina, 2002).

\subsection{Air quality in the Mexico City Metropolitan Area}

Mexico City exhibits the types of environmental problems experienced by megacities around the world and faces the common obstacles to solving them. Air pollution in megacities is strongly influenced by many factors, including topography, meteorology, industrial growth, transportation needs, and expanding populations. The Mexico City Metropolitan Area $\left(19^{\circ} 25^{\prime} \mathrm{N}\right.$ Latitude and $99^{\circ} 10^{\prime} \mathrm{W}$ Longitude) lies in an elevated basin at an altitude of $2240 \mathrm{~m}$ above mean sea level. The nearly flat floor of the basin covers about $5000 \mathrm{~km}^{2}$ of the Mexican Plateau and is confined on three sides (east, south and west) by mountain ridges but with a broad opening to the north and a narrower gap to the south-southeast. A topographical map of the MCMA is shown in Fig. 1.

During the twentieth century the MCMA experienced huge increases in population and urbanized area as it attracted migrants from other parts of the country and industrialization stimulated economic growth. The population grew from fewer than 3 million in 1950 to over 18 million in 2000. New residents continually occupied and urbanized areas further away from the historic center of the Federal District. In just over a half century, urbanized area within the MCMA increased more than a factor of ten, from just $120 \mathrm{~km}^{2}$ in 1940 to $1500 \mathrm{~km}^{2}$ by 1995 . This expansion pushed the city beyond the Federal District and into other municipalities of the State of Mexico and other neighboring states. Currently, MCMA encompasses the 16 delegations of the Federal District, 37 municipalities of the State of Mexico and 1 municipality of the State of Hidalgo (Lezama et al., 2002).

The topography and meteorology of the MCMA contribute substantially to its air pollution. The surrounding mountains, together with frequent thermal inversions, trap pollutants within the MCMA basin during the early hours of the day but are followed by efficient afternoon venting due to terrain-induced winds. The city's high elevation and relatively low latitude lead to intense sunlight, promoting photochemical processes that drive the formation of ozone and other oxidants. In this geographical setting, the metropolitan area's almost 20 million residents, over 3.5 million vehicles, and over 40000 industries consume more than 40 million liters of petroleum fuels per day. Stationary and mobile fossil fuel combustion sources produce thousands of tons of directly emitted pollutants that react in the atmosphere to generate secondary pollutants that can be more dangerous to health than the primary pollutants. Air pollution is generally 
worst in the winter, when rain is less common and thermal inversions are more frequent (Molina and Molina, 2002).

Both the Mexican government and citizens have recognized air pollution as a major social concern since the mid1980s. During the past decade, the Mexican government has made tremendous progress in improving air quality. Substantial reductions in the concentrations of some criteria pollutants (such as lead, carbon monoxide and sulfur dioxide) were achieved by developing and implementing comprehensive air quality management programs and improving air quality monitoring and evaluation programs (Molina and Molina, 2002).

Despite these important gains, serious air pollution problems still persist. MCMA residents remain exposed to unhealthy concentrations of air-borne pollutants, especially particulate matter (PM) and ozone, two of the most important pollutants from the standpoint of public health.

In 1999, the Metropolitan Environmental Commission (Comisión Ambiental Metropolitana, CAM) contracted the MIT Mexico City Project to request help in designing a strategic plan for its new ten-year (2000-2010) air quality management program. Project investigators prepared a series of white papers for CAM, including a review of the state of understanding of air pollution science in the MCMA, lessons learned from air quality management programs to date, and recommendations for research and institutional change so that cost-effective measures can be efficiently developed and implemented. The white papers provided the foundation for the strategic planning for the new ten-year air quality management program prepared by the Mexican authorities (CAM, 2002) and resulted in the publication of a book on integrated assessment of air quality in the Mexico megacity (Molina and Molina, 2002).

The project's assessments of previous MCMA air quality measurements as well as ongoing attempts to model photochemical episodes captured in prior measurement campaigns highlighted the need for more extensive experimental data from field measurements to update and improve the MCMA emissions inventory and to improve the current knowledge of the chemistry, dispersion and transport processes of the pollutants emitted to the MCMA atmosphere (Molina et al., 2002).

One key requirement was a better understanding of VOC and $\mathrm{NO}_{\mathrm{x}}$ emissions inventories; for instance, available VOC emission inventories had to be increased by a factor of 2 to 3 in state-of-the-art photochemical models in order to obtain daily ozone peaks as high as those recorded during the 1997 IMADA-AVER (Investigación sobre Materia Particulada y Deterioro Atmosférico, Aerosol and Visibility Evaluation Research) field campaign (Doran et el., 1998; Edgerton et al., 1999; Molina et al., 2002). MCMA mobile source emissions are suspect given the MCMA's wide range of heavy and light duty vehicles and extremely congested traffic (Gakenheimer et al., 2002). A second key requirement was to better characterize both the emission/formation dynamics and chemical content of fine $\left(\mathrm{PM}_{2.5}\right)$ aerosol particles, which penetrate the lung most efficiently (Evans et al., 2002; Pope and Dockery, 2006). There has been little available data for MCMA PM 2.5 , but strong evidence of adverse health effects from airborne particles based on available $\mathrm{PM}_{10}$ data (Evans et al., 2002; Rosas-Perez et al., 2006). A third measurement goal was to test the accuracy of routine, commercial air quality instrumentation such as that deployed at the monitoring sites of the Mexico City Ambient Air Monitoring Network (Red Automática de Monitoréo Atmosférico, RAMA), which are similar to those used by the US Environmental Protection Agency (EPA).

In order to begin to investigate these issues, as well as to determine how well we could field and utilize research grade atmospheric chemistry instrument suites in the MCMA environment, innovative exploratory mobile and fixed site field measurements, funded by CAM, were performed during February 2002. This was followed by the intensive MCMA2003 field measurement campaign in the spring of 2003.

Preliminary results of the MCMA 2002/2003 measurements were presented at a special session on "Megacity Impacts on Air Quality" at the American Geophysical Union Fall Meeting held on 13-17 December 2004 in San Francisco, California. Major findings from the MCMA-2003 Campaign have been published in a special issue of Atmospheric Chemistry and Physics (ACP) (www. atmospheric-chemistry-and-physics.net) as well as in other peer-reviewed journals. Currently 22 papers have been published by ACP, a few more have been accepted and should be published soon, and several additional papers are under review and have been published in Atmospheric Chemistry and Physics Discussions (ACPD). In addition, 16 papers have been published elsewhere. A complete list is posted at the website of the Molina Center for Energy and the Environment (MCE2): http://mce2.org/publications.html.

This overview is divided into the following sections: Scope of the MCMA-2002/2003 Campaigns (Sect. 2); MCMA Meteorology and Dynamics (Sect. 3), MCMA Emissions of Gases and Fine PM Pollutants (Sect. 4); Measurements of MCMA Volatile Organic Compounds (Sect. 5); MCMA Photochemistry (Sect. 6); MCMA Particulate Matter (Sect. 7); Instrumentation Advances (Sect. 8). A short summary is presented in Sect. 9 .

\section{MCMA-2002/2003 project scope}

\subsection{Exploratory MCMA field campaign - February 2002}

An exploratory research campaign was conducted during 724 February 2002 utilizing a mobile laboratory developed at Aerodyne Research Inc. (ARI) and equipped with a real-time trace gas and particle diagnostics as well as other air quality monitoring instruments (Kolb et al., 2004). During the exploratory mission, the mobile lab operated in three modes: 
(1) stationary deployments at selected RAMA monitoring sites were used to measure diurnal pollution levels in various sectors of the MCMA and to provide high time resolution research instrument data for selected pollutants to help validate and amplify data from the monitoring instruments; (2) mobile measurements were made through selected city sectors to map ambient pollutant levels and to sample and characterize mobile and fixed site emission plumes; and (3) dedicated on-road chase experiments were mounted to better characterize gaseous and particulate emissions from selected classes of vehicles, including heavy-duty diesel trucks, buses, and colectivos (ubiquitous small gasoline or condensed natural gas (CNG) powered microbuses).

Washington State University (WSU) collected VOC whole air samples at selected sampling points within the urban area using portable canister samplers; individual VOC was analyzed with capillary column gas chromatography using flame ionization detection (GC/FID). Four fixed mobile units provided by Mexican institutions were located at the boundary sites (Chalco, Ajusco, Teotihuacan and Cuautitlan) to measure criteria pollutants and meteorological parameters. Additional meteorological measurements were obtained using a tethered balloon and pilot balloons launched by Mexican researchers and radionsondes deployed by the Mexican National Weather Service (Servicio Meteorológico Nacional, SMN).

\subsection{MCMA-2003 campaign}

With the successful completion of the 2002 Exploratory Mission and the financial support from CAM, the MIT-led experimental team planned an intensive, five-week field campaign from 31 March to 4 May 2003. The campaign's field measurement phase was designed to cover the height of the annual photochemical pollution season just prior to the onset of the rainy season and was planned to include measurements taken before, during, and after Holy Week (14-20 April 2003). During this week vehicular traffic is historically reduced as many of the residents leave the city for holidays. It was anticipated that by taking measurements before, during and after Holy Week, a better assessment of the vehicular emissions contribution to the air quality reduction in this megacity could be assessed with regard to oxidant and aerosol levels. Unlike the February 2002 exploratory field campaign that focused primarily on mobile laboratory measurements, the 2003 campaign also involved a highly instrumented "supersite" co-located with the campaigns headquarters at the National Center for Environmental Research and Training (Centro Nacional de Investigación y Capacitación Ambiental or CENICA), a component of the National Institute of Ecology (Instituto Nacional de Ecología or INE).

Based on the Mexico City Project's original assessment of the MCMA air pollution problem (Molina and Molina, 2002) and analyses of the February 2002 campaign data, the multi- national team adopted the following four scientific goals for the MCMA-2003 field campaign:

Goal 1: Develop an improved temporally (diurnal, weekday/weekend) and spatially resolved VOC and $\mathrm{NO}_{\mathrm{x}}$ $\left(\mathrm{NO}+\mathrm{NO}_{2}\right)$ emissions inventory for Mexico. Emphasize understanding the role of mobile versus stationary sources as well as emission sources of aldehydes, aromatics, and other organics with high ozone and secondary organic particulate formation potential.

Goal 2: Because of its key role in ozone production and direct toxic health threat, develop a better understanding of formaldehyde (HCHO) urban atmospheric chemistry. Use vehicle emissions ratios for $\mathrm{HCHO} / \mathrm{CO}_{2}$ and diurnal $\mathrm{HCHO}$ atmospheric concentrations to assess direct emission versus in situ photochemistry source strengths.

Goal 3: Identify major fine airborne aerosol components (sulfate, nitrate, ammonium, organics) and correlate aerosol composition patterns with major sources of secondary aerosol precursor gases such as $\mathrm{SO}_{2}, \mathrm{NO}_{\mathrm{x}}, \mathrm{NH}_{3}$, and selected VOCs.

Goal 4: Develop a better understanding of $\mathrm{NO}_{\mathrm{y}}$ ambient levels and partitioning during photochemical episodes in Mexico City and to better constrain the $\mathrm{NO}_{\mathrm{y}}$ budget and identify how critical components evolve during diurnal cycles.

In order to do the best possible job in reaching these scientific goals, the mobile laboratory and fixed site instrumentation were upgraded for the spring 2003 campaign with supplemental funds from the US National Science Foundation and Mexican Petroleum (Petróleos Mexicanos, PEMEX); the participation of European investigators through the MIT Alliance for Global Sustainability (AGS), as well as participation of many US research teams at the supersite supported by other resources.

The fixed "supersite" capability at CENICA was enhanced with state-of-the-art instrumentation contributed by the US and European teams. CENICA is housed in a laboratory building on the Iztapalapa campus of the Metropolitan Autonomous University (Universidad Autónoma Metropolitana, UAM). CENICA maintains its own suite of routine (EPA level) air quality monitoring instruments for criteria pollutants and also has an automated sampling system for GC/FID analysis of VOCs. In addition, the automatic monitoring network RAMA maintains two nearby official air quality monitoring sites.

During the MCMA-2003 campaign, a tall flux tower was erected on the roof top of CENICA for continuous micrometeorological flux measurements of carbon dioxide, water vapor, total olefins and selected VOCs. The CENICA site also hosted collaborative measurements from various US and European institutions, including (i) $\mathrm{HO}_{\mathrm{x}}$ concentrations and $\mathrm{OH}$ reactivity measurements from Penn State; (ii) a GCbased peroxyacetyl nitrate (PAN) instrument, an open-path near infrared ammonia vapor instrument, a Luminol chemiluminescent instrument for semi-continuous olefin measurements, and aethalometer for black carbon determinations 
from the Argonne National Laboratory (ANL); (iii) nitroPAH measurements from University of California, Riverside; (iv) an aerosol mass spectrometer (AMS) from University of Colorado; (v) a proton transfer reaction mass spectrometer (PTR-MS) and several radiometers and particle sampler from Pacific Northwest National Laboratory (PNNL); (vi) two research lidars from Swiss Federal Institute of Technology (EPFL) and from MIT/Free University of Berlin (FUB), and a commercial lidar from Elight; (vii) two research grade visible/near ultraviolet differential optical analysis spectroscopy (DOAS) instruments provided by the University of Heidelberg and operated by the MIT team; (viii) mini-DOAS and FTIR spectrometers from Chalmers University of Technology.

A key feature of the spring MCMA-2003 campaign was the deployment of a new and larger mobile laboratory equipped with additional instruments developed by ARI as well as contributed by participating collaborators, including a quantum cascade tunable infrared laser differential absorption spectrometer (QC-TILDAS) to measure gaseous ammonia $\left(\mathrm{NH}_{3}\right)$ from ARI, a commercial total nitrogen oxide $\left(\mathrm{NO}_{\mathrm{y}}\right)$ from MIT; a customized GC-instrument to measure PAN from ANL, an aethalometer from Lawrence Berkeley National Laboratory (LBNL), and a customized impactor to collect fine particles for subsequent synchrotron X-ray analysis provided by PNNL. These additional instruments, coupled with the fast response trace gas and fine particle instrumentation from the original ARI mobile laboratory, allowed a wide range of experiments to be pursued during the MCMA-2003 Campaign. When not involved in mobile mapping, chase or other off site experiments, the mobile laboratory was sited at CENICA and its instrument suite contributed to the supersite's database.

As in the February 2002 campaign, RAMA, CENICA, and the Secretary of Ecology of the State of Mexico (Secretaría de Ecología, Gobierno del Estado de Mexico, SEGEM) deployed mobile units containing standard commercial air quality and meteorological instrumentation at several sites near the edge of the Valley of Mexico to monitor the air entering and leaving the valley (See Fig. 1). Meteorological parameters were obtained from tethered balloons, pilot balloons, radiosondes and sodars deployed by collaborating Mexican and US teams. IMP participants complemented the measurements with sampling and chemical characterization of fine particles at three sites using MINIVOLS and MOUDI devices, as well as total carbonyls and its chemical speciation at several sites.

The instrumentation deployed during the campaign is described in more details in the following sections. A list of key participating institutions and instrumentation is presented in Table 1; a complete list is available at the MCE2 website (http://www.mce2.org/).

\section{MCMA meteorology and dynamics}

Three questions guided the analysis of the meteorological observations during MCMA-2003 Campaign:

1. What is the nature of the mixed layer?

2. What is the impact of pollutant carry-over from day to day?

3. How good is the performance of mesoscale meteorological models?

A combination of operational and intensive observations were used to address these questions as well as provide wind transport analyses for interpreting MCMA-2003 aerosol and gas phase measurements.

\subsection{Observational resources}

The location of MCMA meteorological observation sites is shown in Fig. 1. Surface meteorological measurements were available from the automatic network of the Mexican National Weather Service (SMN) for 60 stations nationwide, of which 6 were in the Valley of Mexico basin. Of the 36 RAMA monitoring sites in the basin, 15 have meteorological stations. The National Autonomous University of Mexico (Universidad Nacional Autónoma de México, UNAM) operated 5 stations, plus its high-school network consisting of 18 surface sites (not shown in the map). CENICA obtained measurements at the campaign supersite as well as at their Revolucion laboratory located at the southwest part of the city. Together, these stations provided extensive spatial coverage of the basin, enabling the identification of surface wind circulation features. During the 2003 campaign, mobile units were deployed at four boundary sites: Santa Ana Tlacotenco, Cerro Catedral, ININ and La Reforma (Hidalgo). These measured meteorological parameters as well as criteria pollutants, establishing boundary conditions and detecting the transport of the urban plume out of the basin.

In the vertical, radiosonde observations were available from SMN every $6 \mathrm{~h}$ at their headquarters in Mexico City and once a day at 12:00 UTC at other locations throughout the country. Radiosonde data are used to determine the synoptic meteorological conditions and to initialize the global meteorological models upon which the mesoscale simulations rely. The profiles every $6 \mathrm{~h}$ provided information on the day-today variation of the boundary layer.

Three tethered balloons were used to characterize the morning mixing layer at the CENICA supersite (CENICA and EPFL) and at Cuautitlán (MIT/UNAM), providing wind, pressure, temperature and humidity measurements up to $1000 \mathrm{~m}$ above ground level. At CENICA these balloons were launched during 5 days of the campaign, with profiles carried out every $2 \mathrm{~h}$ starting at 3:00 am local time until the early afternoon when the strength of the winds precluded further 
Table 1. List of participating institutions and instruments deployed during MCMA 2002/2003 campaign.

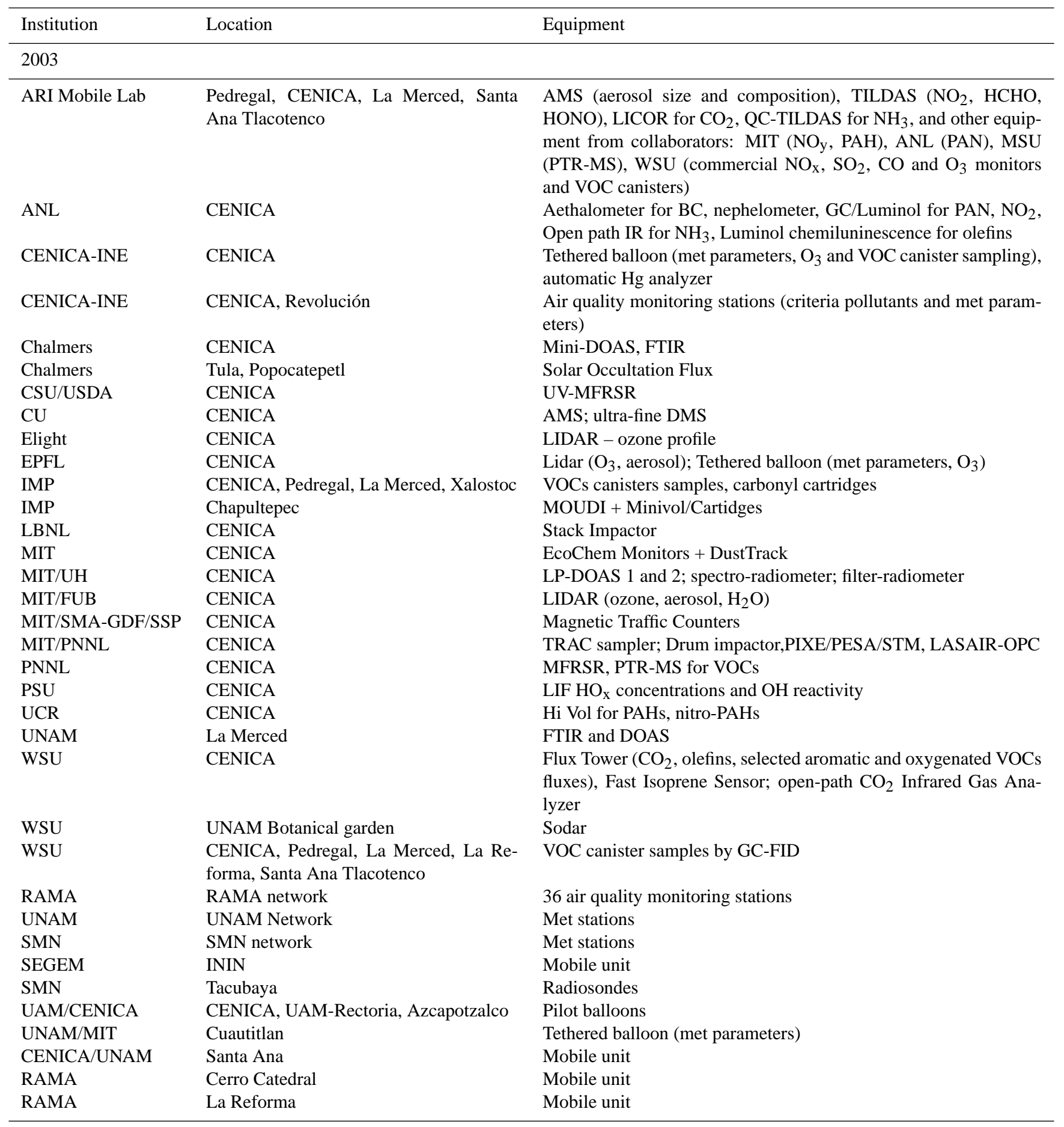

soundings. Measurements during the night enabled the observation of the drainage flows and the nighttime boundary layer as well as its morning evolution. A SODAR was deployed in the botanical gardens at UNAM, measuring threedimensional winds up to $600 \mathrm{~m}$ above ground level in the southern part of the city.
Pilot balloons were released simultaneously from 3 sites around the basin every $2 \mathrm{~h}$ during the morning and early afternoon. By measuring azimuth and elevation angles every $10 \mathrm{~s}$, wind speeds were calculated throughout the height of the boundary layer, showing spatial variations in the basin's vertical wind patterns (de Foy et al., 2006c). 
Table 1. Continued.

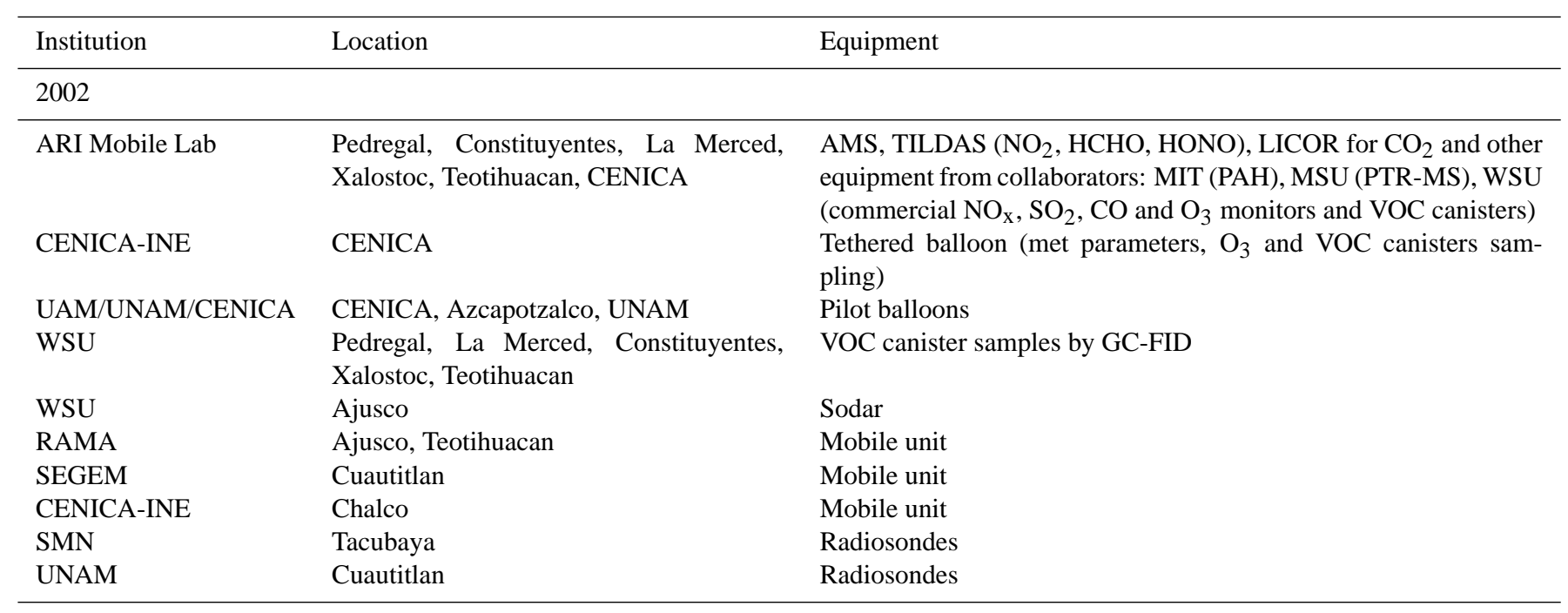

KEY:

ARI - Aerodyne Research, Inc.

ANL - Argonne National Laboratory

CENICA - Centro Nacional de Investigación y Capacitación Ambiental

Chalmers - Chalmers University of Technology

CSU - Colorado State University

CU - University of Colorado, Boulder

EPFL - Swiss Federal Institute of Technology

FUB - Free University of Berlin

IMP - Instituto Mexicano de Petróleo

INE - InstitutoNacional de Ecología

LBNL - Lawrence Berkeley National Laboratory

MIT - Massachusetts Institute of Technology

MSU - Montana State University

PNNL - Pacific Northwest National Laboratory

PSU - Pennsylvania State University

RAMA - Red Automática de Monitoréo Atmosférico

SEGEM -Secretaría de Ecologia, Gobierno de Estado de Mexico

SMA-GDF - Secretaría de Medio Ambiente, Gobierno de Distrito Federal

SMN - Servicio Meteorológico Nacional

SSP - Secretaría de Seguridad Pública

UAM-I - Universidad Autónoma Metropolitana - Iztapalapa

UCR - University of California, Riverside

UH - University of Heidelberg

UNAM - Universidad Nacional Autónoma de México

USDA - U.S. Department of Agriculture

WSU - Washington State University

LIDARs sited at CENICA measured continuous vertical profiles of ozone and aerosol backscatter (Frey et al., 2004; Ristori et al., 2004; Simeonov et al., 2004). Their high spatial and temporal resolution as well as continuous time coverage enabled detailed observation of the boundary layer evolution above the supersite. A three axis sonic anemometer located on the flux tower at CENICA super- site (Velasco et al., 2005a, b) recorded wind speeds at $10 \mathrm{~Hz}$, providing turbulence measurements, latent heat fluxes and sensible heat fluxes.

\subsection{Meteorological overview}

Several field campaigns have analyzed the complex wind circulation in the Mexico City basin. In 1991, the Mexico 


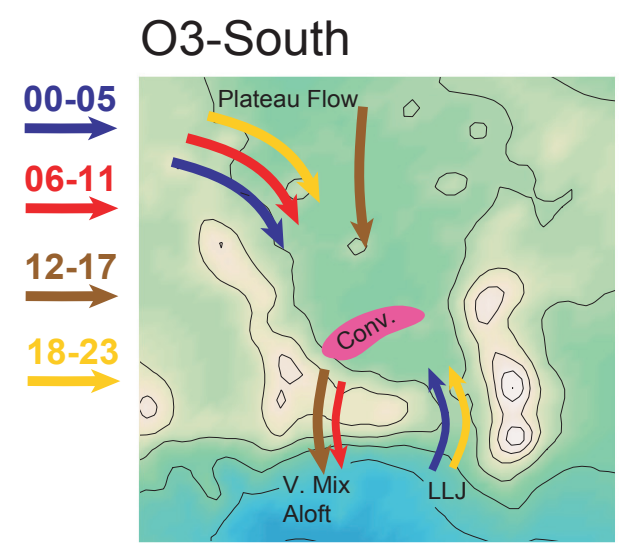

\section{O3-North}

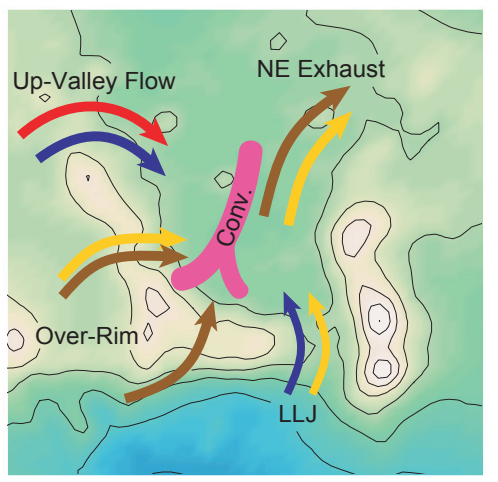

Cold Surge

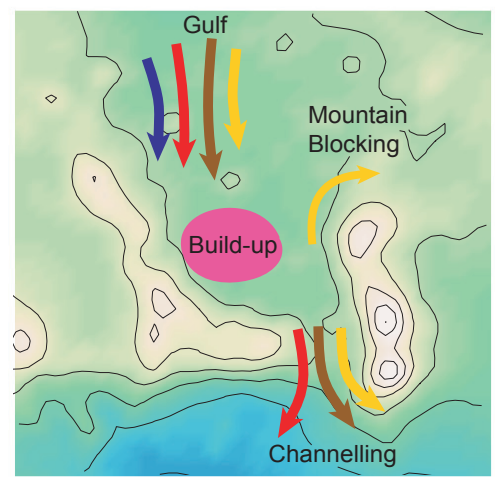

Fig. 2. Circulation Model for the Mexico City basin for O3-South, O3-North and Cold Surge episode types. Arrows colored by time of day: early morning (0-5) in blue, morning (6-11) in red, afternoon (12-17) in brown and evening (18-23) in yellow. Plateau winds on O3-South days combine with vigorous mixing to transport the urban plume southwards of the mountains. A low level jet forms in the Chalco passage causing a convergence line in the south of the city. Strong westerly flow on O3-North days first enters the basin from the northwest but then comes over the south and west rims of the basin during the day. The combination with the low level jet forms a north-south convergence zone and exhaust of the basin to the northeast. On Cold Surge days strong northerly winds blow into the basin. Low mixing heights lead to pollutant accumulation in the city and channel flow through the Chalco passage (Fig. by B. de Foy).

City Air Quality Research Initiative (MARI) measured vertical pollutant distributions due to the interaction of drainage flows and gap flows from outside the basin (Streit and Guzman, 1996). In 1997, the IMADA-AVER Boundary Layer Experiment found short residence times in the basin with rapid ventilation and recirculation aloft due to vertical wind shear (Fast and Zhong, 1998). Subsequent modeling studies have focused on the horizontal wind convergence zone and its impact on air pollution (Jazcilevich et al., 2005).

The MCMA-2003 field campaign was scheduled near the end of the dry season when there is intense solar radiation but limited convective activity. Cold fronts moving into the tropics during the cold season lead to strong cold northerly winds along the coast of the Gulf of Mexico known as cold surges or "El Norte". These bring moisture and rainfall to the Mexican plateau. A strong cold surge occurred just before the campaign and two more followed during the campaign. This led to a more humid month than usual. In particular, the rain from the first cold surge led to a reduction in biomass burning in the region that increased again as the campaign progressed. Of the 34 days in the campaign, 10 were classified as "Cold Surge".

There were two episodes featuring an anti-cyclone over the eastern Pacific leading to weak northerly winds aloft of the MCMA. Thermally driven circulations develop under these conditions with strong sea breezes from both coasts interacting with the mountain breezes in the Mexico City basin. The resulting wind pattern has a northerly flow during the early morning and afternoon followed by a low level gap flow from the southeast; this forms a convergence zone that moves northward into the early evening. High ozone levels in the south of the city are associated with these events. The two episodes lasted for a total of 7 days and were classified as "O3-South".

The rest of the MCMA-2003 Campaign was characterized by low-pressure systems moving over the US but little activity over Mexico. Stronger westerly winds aloft due to the sub-tropical jet had a southerly component above Mexico City. As the mixing height grew during the day, down mixing of momentum led to a reinforcement of the low-level gap flow and to southwesterly flow over the basin rim. A north-south convergence line formed with pollutant transport in the afternoon to the northeast. Because the convergence line moved little during the afternoon, these days experienced the highest ozone levels of the campaign with peak concentrations in the north of the city. Two major episodes and three short transition periods featuring these conditions covered 17 days, which were classified as "O3-North".

The days classified in the three episode types, Cold Surge, O3-South and O3-North, experienced broadly similar wind patterns, cloud cover and pollutant levels (de Foy et al., 2005). Conceptual wind circulation patterns for each episode are shown in Fig. 2. Averaging according to episode type produced meaningful diurnal patterns constructed from time series meteorological and pollutant data collected during the campaign. For example, plotting the range and inter-quartile range of diurnal profiles of ozone classified by episode type shows distinct afternoon behavior with little overlap between the episode types.

The nature of the mixed layer in the basin is strongly influenced by its high elevation, intense heating and low moisture content, as well as the physical barrier of the surrounding mountains. Mixed layer heights diagnosed from radiosonde observations during the campaign ranged from 3 to $4 \mathrm{~km}$ 
above ground level. LIDAR measurements revealed fluctuations on short time scales in the layer height due to horizontal variations in wind currents. At night, a small residual layer was sometimes observed aloft. At the surface, a persistent layer of mechanical mixing reaching up to $500 \mathrm{~m}$ was frequently seen. Rapid and thorough mixing during the day gave way to decoupling in the late afternoon with a residual ozone layer aloft in the early evening (Frey et al., 2004; Ristori et al., 2004).

\subsection{Meteorological modeling studies}

Meteorological mesoscale model simulations and evaluations are inherently uncertain for complex terrain cases with weak synoptic forcing. Furthermore, Mexico City has an urban heat island with potential impacts on the wind circulation (Jauregui, 1997; Jazcilevich et al., 2002). Land surface properties derived from satellite remote sensing using the MODIS instrument were used to improve the representation of surface heat fluxes in MM5 (de Foy et al., 2006b). This led to improved temperature, humidity and wind simulations on the fine scale $(3 \mathrm{~km})$ simulations. The nighttime urban heat island was clearly seen from the MODIS data. The refinements of the land surface in the model are a necessary first step to using and evaluating more sophisticated urban modules within mesoscale models.

Modeling studies of the gap flow confirmed the influence it has on basin cooling, leading to a sharp drop in the mixed layer height near sunset (Doran and Zhong, 2000). While similar measurements were not available, the simulated heat balance across the southern basin rim varied little, and the wind direction aloft was found to be the main predictor of the variations in gap flow for O3-South episodes with no clear predictor for the other episodes that could be determined from available data (de Foy et al., 2006a).

Pollutant carry-over from day to day is an important factor in urban air pollution and computational assessments can lead to important insights. Pilot balloon measurements were used to validate a Lagrangian trajectory model (de Foy et al., 2006c). Numerical estimates of the residence time of air parcels in the basin suggested rapid pollutant export from the basin and limited recirculation fractions that vary by episode type. Patterns of pollutant export to the regional environment also varied by episode type and some larger scale recirculation was found for O3-South days.

Dispersion modeling of carbon monoxide was used in combination with total $\mathrm{CO}$ column measurements to suggest that vertical diffusion schemes must be carefully selected before recommending adjustments to the emission inventory (de Foy et al., 2007). Lagrangian trajectories were able to reconstruct emissions of $\mathrm{CO}$ and distinguish between the impacts of large $\mathrm{SO}_{2}$ point sources (de Foy et al., 2007), thereby providing further validation of the trajectory quality.

\section{MCMA emissions of gaseous and fine PM pollutants}

Characterizing and quantifying the emissions of both gaseous pollutants and primary PM is a difficult task in any major urban area, but it presents a particularly daunting task in a rapidly developing megacity like the MCMA. As mentioned in Sect. 1.2, Mexico City is characterized by an expanding population and rapidly changing economic and social conditions; changes that impact both the quantity and speciation of gaseous and PM emissions, making the development of accurate emissions inventories a fast moving target (Molina and Molina, 2002).

\subsection{MCMA emissions inventories}

Further challenges arise from the fact that the development of traditional "bottoms up" emission inventories is a relatively new activity in Mexico. While the first estimates of pollutant emissions in MCMA were made in the 1970s, initial efforts were hampered by a lack of actual emissions measurements and addressed a very limited number of species. The first systematic emissions inventory (EI) attempted was published in 1988 for use in the MCMA's inaugural air quality assessment, the Integrated Program for Atmospheric Pollution Control (Programa Integral Contra la Contaminación Atmosférica, PICCA). Starting in 1994 the Environment Secretary of the Federal District Government (Secretaria de Medio Ambiente, Gobierno de Distrito Federal, SMA-GDF) has published biennial MCMA EI's. However, from the first systematically released 1994 EI up to the most recently published 2004 EI (CAM, 2006), emission estimates were based on the use of measured and/or modeled emission factors, which were either locally measured or adapted from other locations. Substantial efforts have been made to increase the use of local measurements of emission factors in the most recent published EIs. When model estimates of emission factors were made, the models were adjusted to local conditions whenever possible. Despite these efforts, important emission estimates from various emission sources relied upon non-local emission factors that were not necessarily appropriate for the MCMA's unique combination of meteorology, topography, altitude, and social practices (Molina and Molina, 2002). Efforts to develop the first comprehensive national emissions inventory (for the year 1999) for Mexico was started by INE in 2000 (NARSTO, 2005); it was released in September 2006 (INE-SEMARNAT, 2006).

Prior to 2002, MCMA ambient and direct emissions measurements clearly indicated that leaks from the city's liquefied petroleum gas (LPG) system, the main fuel for MCMA cooking and water heating, and on-road motor vehicle emissions, from more than 3.5 million vehicles with an average age of $\sim 9$ years, produced large amounts of photochemically active species. LPG leakage was shown to produce high ambient concentrations of propane, butanes and other low molecular weight alkanes and alkenes (Blake and 
Rowland, 1995; Arriaga et al., 1997), while motor vehicle emissions were responsible for substantial levels of $\mathrm{NO}_{\mathrm{x}}$, $\mathrm{CO}$, and a number of highly reactive aromatic and olefinic VOCs (Bishop et al., 1997; Mugica, et al., 1998, 2003; Schifter et al., 2003). Schifter et al. (2005) recently published retrospective fuel-based motor vehicle emissions inventory estimates for 1980-2000 based primarily on the prior remote sensing vehicle measurements noted above. Additional work on restaurant and roadside food vendor cooking emissions (Mugica et al., 2001); VOC receptor modeling (Vega et al., 2000), and fugitive dust emissions (Vega et al., 2001) provided valuable insights about other important pollution sources. Estimating emissions from more than 40000 MCMA industrial sites, many of them relatively small, is particularly challenging. ${ }^{1}$

Both analyses of ambient $\mathrm{CO}$ and VOC measurements (Arriaga-Colina et al., 2004) and photochemical model comparisons with measured ozone and nitrogen oxide levels (West et al., 2004) cast serious doubt on the accuracy of EI evaluations available before 2003. Estimates of normal (nonfire) biogenic NO and VOC emissions indicate that they are a very small fraction of total MCMA emissions (Velasco, 2003). Given the uncertainties of MCMA EIs available in 2002/2003 and the clear need to better characterize the emissions of gaseous and PM species from anthropogenic sources that contribute to the high levels of photochemical oxidants and fine PM levels observed in the MCMA, several ambient measurement methods to better assess the emissions of VOCs, $\mathrm{NO}_{\mathrm{x}}, \mathrm{NH}_{3}$, and primary fine particles were developed and deployed during MCMA 2002/2003.

\subsection{Mobile emissions measurements}

One major emissions measurement facility, fielded by ARI in both the MCMA-2002 exploratory campaign and during MCMA-2003, was a van borne mobile laboratory equipped with a unique set of real-time trace gas and fine PM instruments to better characterize on-road vehicle emissions as well as to identify and characterize point and area source emissions plumes (Kolb et al., 2004; Herndon et al., 2005). Emission indices (g pollutant/kg fuel burned) can be computed from fast response (1-2s) correlations of excess (above background) exhaust plume trace gas or PM components to excess plume $\mathrm{CO}_{2}$, using tunable infrared laser differential absorption spectroscopy (TILDAS), PTR-MS, or chemiluminescence measurements (CL) for gaseous species, while aerosol mass spectrometry (AMS) provides fast response non-refractory fine particle composition measurements. Emissions from specific types of vehicles can be

\footnotetext{
${ }^{1}$ According to the 2004 Emissions Inventory (CAM, 2006): There are about 42000 micro-industries, 4200 small and medium size industries and 460 large industries. The point sources emissions estimates in the 2004 EI were constructed with information from about 4900 industries, which include large and medium size industries; the missing ones are all in the "small" category.
}

characterized in "chase" mode where the target vehicles' exhaust plumes are repeatedly sampled as their driving mode changes; while "fleet average" emission indices can be acquired by randomly sampling plumes from many vehicles as they pass the mobile laboratory traveling in either direction. Somewhat less reliable fleet average emissions can be obtained using slower response (5-30 s) instruments to correlate on-road pollutant levels with appropriately averaged intervals of excess $\mathrm{CO}_{2}$.

The MCMA-2003 measurements represent the first use of a PTR-MS to investigate on-road vehicle VOC emissions. Details of the on-road PTR-MS measurement technique have been presented by Rogers et al. (2006). Zavala et al. (2006) present MCMA 2002/2003 on-road exhaust emission ratios (excess plume pollutant ppbv/excess plume $\mathrm{CO}_{2}$ ppmv) for $\mathrm{NO}, \mathrm{NO}_{2}, \mathrm{NH}_{3}, \mathrm{HCHO}, \mathrm{CH}_{3} \mathrm{CHO}, \mathrm{C}_{6} \mathrm{H}_{6}, \mathrm{CH}_{3} \mathrm{C}_{6} \mathrm{H}_{5}, \mathrm{MBTE}$ + butenes, $\mathrm{C} 2$-benzenes and $\mathrm{C} 3$-benzenes for various classes of both gasoline and diesel fueled vehicles. These ratios can be used to compute fuel based emission indices and combined with MCMA fleet composition and fuel usage to estimate total annual emissions. The annual vehicle $\mathrm{NO}_{\mathrm{x}}$ emissions estimate by Zavala et al. (2006) agrees well with the $2002 \mathrm{EI} \mathrm{NO}_{\mathrm{x}}$ attributed to mobile sources (CAM, 2004) and the fuel based EI based on 2002 remote sensing studies analyzed by Schifter et al. (2005). Jiang et al. (2005) analyzed mobile laboratory slower response instrument data to estimate fleet average emissions of black carbon, PM bound polycyclic aromatic hydrocarbons (PPAHs), $\mathrm{NO}_{\mathrm{x}}, \mathrm{CO}$, and $\mathrm{PM}_{2.5}$, they also extrapolated PTR-MS VOC data to estimate total exhaust VOC emissions. Their $\mathrm{NO}_{\mathrm{x}}$ and $\mathrm{PM}_{2.5}$ estimates compare well with official 2002 vehicle emission estimates (CAM, 2004). There are no official EI estimates for PM-associated black carbon or PAHs. In 2003 the ARI mobile laboratory also deployed a conditional sampling system designed to collect separate canister samples of exhaust plume enriched air and on-road background air for subsequent gas chromatographic analysis (Herndon et al., 2005, $2007^{2}$ ). These data, after regressions analyses to correct for photochemical losses, have been correlated with ambient VOC canister samples to determine which ambient VOC concentrations are dominated by vehicular emissions (Velasco et al., 2007).

A second mobile emissions characterization facility, from Chalmers University of Technology, consisted of a vehiclemounted miniature Differential Optical Absorption Spectrometer (mini-DOAS) instrument designed to remotely sense and characterize $\mathrm{SO}_{2}$ emission plumes using zenith sky ultraviolet measurements of $\mathrm{SO}_{2}$ column density concentration variations (Galle et al., 2003) and a solar FourierTransform Infrared (FTIR) instrument primarily used to

\footnotetext{
${ }^{2}$ Herndon, S. C., Kolb, C. E., Lamb, B., Westberg, H., Allwine, E., Velasco, E., Knighton, B., Zavala, M., Molina, L. T., and Molina, M. J.: Conditional sampling of volatile organic compounds in on-road vehicle plumes, in preparation, 2007
} 
characterized $\mathrm{CO}$ column concentrations. Measurements of $\mathrm{SO}_{2}$ plumes from a large power plant and refinery complex in Tula and the Popocatépetl volcano have been used to assess the ability of models to effectively incorporate large scale point emission sources, while CO column measurements were used to assess if models can be used to constrain the MCMA CO EI (de Foy et al., 2007).

\subsection{Fixed site emissions measurements}

Fixed site long open-path spectroscopic measurements also yielded valuable emission information as they quantified the increases in motor vehicle exhaust species during the morning rush hour or intercepted fixed source plumes as wind changes sampled surrounding sources. Two separate research grade long-path DOAS instruments supplied by the University of Heidelberg and operated by MIT, one of which was co-aligned with an open-path FTIR from Chalmers, were deployed at the CENICA site (Volkamer et al., 2005a, b). Open-path FTIR and commercial DOAS instruments were operated at La Merced site by UNAM (Grutter et al., 2005). Correlating the build up of morning rush hour pollutant concentrations with rising ambient $\mathrm{CO}_{2}$ allowed estimates of motor vehicle emissions indices for $\mathrm{NO}, \mathrm{N}_{2} \mathrm{O}, \mathrm{NH}_{3}, \mathrm{CO}$, $\mathrm{CH}_{4}, \mathrm{C}_{2} \mathrm{H}_{2}, \mathrm{C}_{2} \mathrm{H}_{6}, \mathrm{C}_{3} \mathrm{H}_{8}$, and $\mathrm{HCHO}$ at La Merced and $\mathrm{NO}, \mathrm{NO}_{2}, \mathrm{~N}_{2} \mathrm{O}, \mathrm{SO}_{2}, \mathrm{HCHO}, \mathrm{C}_{4} \mathrm{H}_{10}$, and a range of aromatic VOCs at CENICA (Volkamer et al., 2005a). Agreement between the derived emissions indices estimates for species measured by open path methods at both La Merced and CENICA is generally good, although a significantly higher NO value was obtained at La Merced. Most importantly the mean emissions ratios for nitrogen dioxide, formaldehyde, benzene and toluene measured by open path methods at CENICA agreed surprisingly well with the integrated distributions of nearby on-road exhaust plume measurements made with the ARI mobile laboratory. Figure 3 shows mobile emissions estimated from measured on-road emission indices by the ARI mobile laboratory on a wide range of MCMA roadways for $\mathrm{NO}_{\mathrm{x}}$ from light-duty gasoline vehicles (Zavala et al., 2006), and CO and VOC from the full on-road fleet (Jiang et al., 2005), although without distinction of the corresponding type of vehicle and are more likely to represent aggregated emission factors of everything on the road (diesel, gasoline, $\mathrm{LPG}, \mathrm{CNG}$ ) plus some non-road emissions. Figure 3 also shows estimated on-road fleet $\mathrm{SO}_{2}$ emissions determined from $\mathrm{SO}_{2} / \mathrm{CO}_{2}$ concentration growth measurements obtained by long open-path absorption at CENICA (de Foy et al., 2007). These are compared to the relevant MCMA EI estimates for 2002 (CAM, 2004).

Direct flux measurements of trace species using micrometeorological eddy covariance and disjunct eddy covariance techniques are commonly used to characterize natural and agricultural ecosystem fluxes but have seldom been used in urban environments. The WSU group erected a $25 \mathrm{~m}$ scaf-

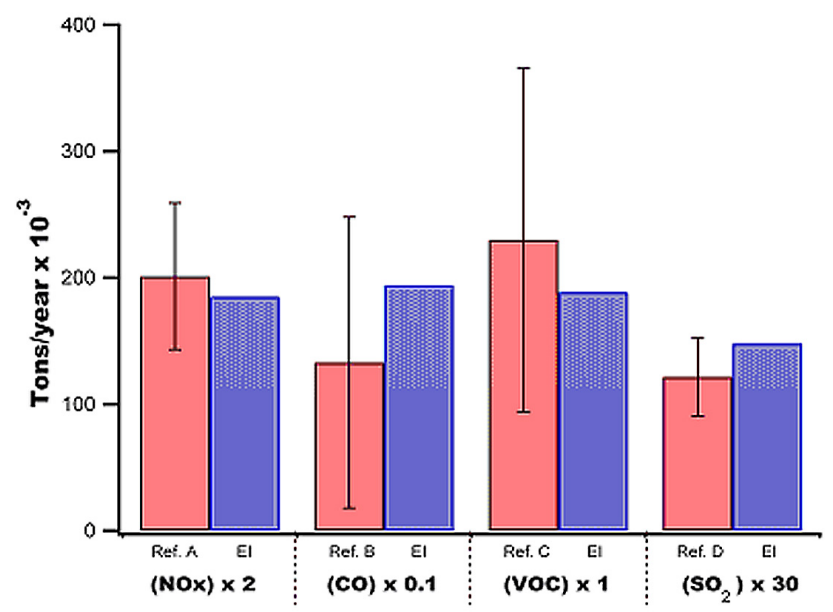

Fig. 3. Comparison of measured 2003 mobile emissions for $\mathrm{NO}_{\mathrm{x}}$ (light duty gasoline vehicles) and $\mathrm{CO}, \mathrm{VOCs}$ and $\mathrm{SO}_{2}$ (all vehicles) with MCMA EI estimates for the year 2002 (Ref. A is Zavala et al., 2006; Refs. B and C are Jiang et al., 2005; Ref. D is de Foy et al., 2007) (Fig. by M. Zavala).

fold flux tower on the $12 \mathrm{~m}$ high rooftop of the CENICA laboratory to perform what we believe are the first eddy covariance flux measurements of trace gases in a developing world city. Diurnal $\mathrm{CO}_{2}$ fluxes at CENICA were correlated with traffic activity, with peak mean morning rush hour values approaching $1 \mathrm{mg} \mathrm{m}^{-2} \mathrm{~s}^{-1}$. The daily mean of $0.41 \mathrm{mg} \mathrm{m}^{-2} \mathrm{~s}^{-1}$ was similar to those observed in U.S. and European cities (Velasco et al., 2005a).

Fluxes of olefins were measured by eddy covariance coupled with a fast-response olefin chemiluminescence sensor (FOS). A PTR-MS from PNNL was used to measure fluxes of acetone, methanol, toluene and $\mathrm{C}_{2}$-benzenes employing the disjunct eddy covariance technique. VOCs fluxes also showed a clear diurnal pattern strongly correlated with traffic intensity. The measured VOCs fluxes were compared to the emissions reported by the local model-based gridded $1998 \mathrm{EI}$ for the part of the city near CENICA, finding that emissions fluxes of olefins, toluene and acetone showed good agreement for this part of the MCMA (Velasco et al., 2005b). These comparisons do not support the idea that the VOCs emissions inventory is underestimated by a factor of 3 , as it was suggested by previous photochemical model comparisons with measured ozone and nitrogen oxide levels (West et al., 2004), and by analysis of ambient CO and VOC measurements (Arriaga-Colina et al., 2004). Furthermore, examination of data from canister samples of ambient air VOC concentrations, taken at various MCMA urban sites during the morning rush hours (6:00 to 9:00 h) and analyzed by GCFID, to determine the relative distribution of lumped modeling VOC classes also did not support a high level of underestimation compared to the emissions inventory for all VOC classes. This comparison suggested that some, but not all, 
VOC classes are underestimated in the emissions inventory by factors of 1.1 to 3; specifically, it suggests that the modelbased 1998 EI (CAM, 2001) underestimates the contribution of some alkanes and overestimates the contributions of some olefins and aromatics (Velasco et al., 2007).

Information on the morning and midday vertical distributions of selected VOCs up to $200 \mathrm{~m}$ was obtained from gas chromatographic analysis of tethered balloon canister samples obtained on seven days at the CENICA site during MCMA 2003 (Wöhnschimmel et al., 2006). Chemical mass balance and linear unmixing receptor modeling identified liquefied petroleum gas and gasoline vehicle exhaust as the major sources of the measured VOCs.

\subsection{Aldehyde emissions versus photochemical production}

One of the key emission issues identified as a MCMA-2003 project goal in Sect. 2.2 and addressed by a variety of measurements involves the sources of atmospheric formaldehyde and, to a lesser extent, acetaldehyde $\left(\mathrm{CH}_{3} \mathrm{CHO}\right)$, in the MCMA atmosphere. Baez et al. (1995) noted very high ambient MCMA levels of formaldehyde and acetaldehyde with both peaking in the morning hours. Very high 2002 and 2003 downtown HCHO levels that also peak in mid-morning, have been documented by Grutter et al. (2005). Schifter et al. (2000) estimated moderate emissions of both aldehydes from MCMA gasoline powered vehicles. However, initial MCMA-2002 ARI mobile laboratory measurements of on-road formaldehyde emission ratios revealed very high exhaust $\mathrm{HCHO}$ concentrations, with $\mathrm{HCHO}$ emission ratios to excess $\mathrm{CO}_{2}$ approximately eight times higher than those encountered in Boston's on-road fleet (Kolb et al., 2004). These high $\mathrm{HCHO}$ emission levels along with high $\mathrm{CH}_{3} \mathrm{CHO}$ ratios were confirmed by the much more extensive MCMA-2003 on-road measurements reported in Zavala et al. (2006), who estimated total on-road MCMA HCHO emissions of over 7 times and $\mathrm{CH}_{3} \mathrm{CHO}$ emissions over 4 times higher than those suggested by Schifter et al. (2000).

It is highly probable that high morning rush hour on-road emissions of these photolytic radical sources play a key role in initiating the vigorous morning photochemistry that characterizes the MCMA atmosphere documented by Shirley et al. (2006). Correlations of the 2003 CENICA DOAS and mobile laboratory TILDAS HCHO measurements with the exhaust marker $\mathrm{CO}$ and the photochemical markers $\mathrm{CHO}$ $\mathrm{CHO}$ and $\mathrm{O}_{3}$ were used to estimate ambient $\mathrm{HCHO}$ levels due to emission and photochemical production (Garcia et al., 2006). These analyses indicate that averaged over the day about $40 \%$ of ambient $\mathrm{HCHO}$ can be attributed to exhaust emissions. The emission source is dominant in the early morning, evening and at night, while the photochemical source becomes dominant later in the morning and produces about $80 \%$ of the ambient $\mathrm{HCHO}$ in the four hours around noon.

\section{Measurements of MCMA Volatile Organic Compounds}

A significant aspect of the MCMA-2003 field campaign was the effort to apply a number of independent methods to measure ambient concentrations of VOCs at various locations within the Valley of Mexico. The use of different techniques allowed a wide range of individual species to be measured over different spatial and temporal scales, providing confidence in the data, as well as a basis for comparison with grid model simulations of selected VOCs. The VOC concentrations were analyzed to understand better their distribution, diurnal pattern, origin and reactivity in the atmosphere of the MCMA. Also, as discussed above in Sect. 4, these VOC data were used to evaluate indirectly the local emissions inventory and, as discussed below in Sect. 6, to provide information to analyze the production of photochemical oxidants.

\subsection{VOC measurement methods}

VOC measurement methods included both standard and new techniques. For example, three-hour averaged canister sampling coupled with gas chromatography/flame ionization detection (GC/FID) or gas chromatography/mass spectrometry (GC/MS) was used to measure the time-averaged concentrations of individual hydrocarbons at a number of fixed sites on a daily basis throughout the campaign. More than 180 samples were collected in this manner from four different commercial/residential locations, three boundary sites in rural areas and one highly industrial section of the city (Velasco et al., 2007). These time-averaged data were complemented by continuous, high time resolution measurements of aromatic and oxygenated VOCs using two PTR-MS instruments. One PTR-MS operated in a fixed mode at the CENICA site (Jobson et al., $2007^{3}$ ) and the other in both fixed site and mobile modes on-board the ARI mobile laboratory (Rogers et al., 2006). The PTR-MS operated in mobile mode in the ARI mobile lab was used to determine on-road vehicle emissions as well as to measure ambient concentrations (Rogers et al., 2006; Zavala et al., 2006; Velasco et al., 2007).

A measure of total olefin concentrations was obtained using a fast-response olefin chemiluminescence sensor (FOS) deployed at the CENICA site. As detailed in Sect. 4.3, the PTR-MS and FOS at the CENICA site provided both ambient VOC data as well as the first ever VOC eddy covariance flux data for an urban area (Velasco et al., 2005b). A unique perspective was provided by open-path DOASs operated at the CENICA and at La Merced sites. These instruments measured a number of specific VOC with very high time resolution, averaged over long path lengths (860 $\mathrm{m}$ at CENICA and

\footnotetext{
${ }^{3}$ Jobson, B. T., Alexander, L., Prazeller, P., Berkowitz, C. M., Westberg, H., Velasco, E., Allwine, E., Lamb, B., Volkamer, R., Molina, L. T., and Molina, M. J.: Intercomparison of volatile organic carbon measurements techniques and data from the MCMA 2003 field experiment, in preparation, 2007.
} 

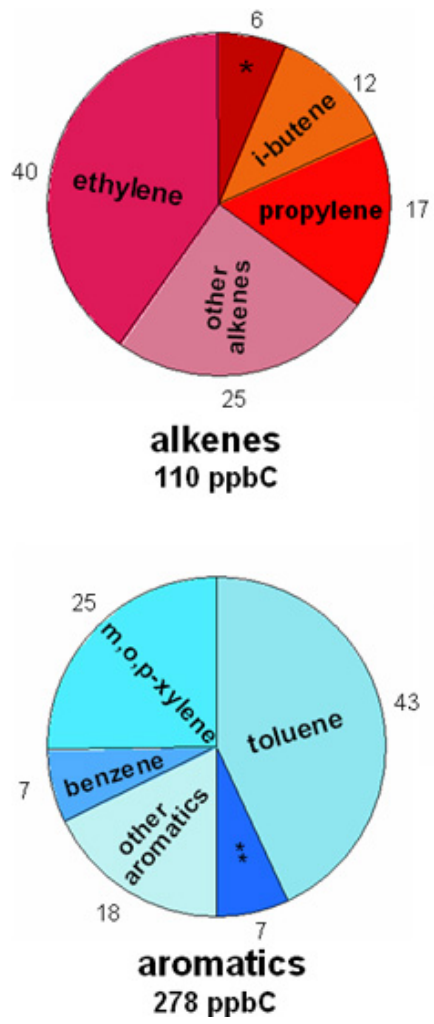

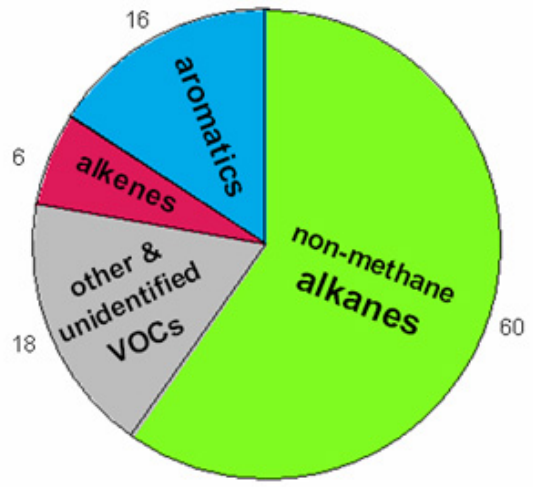

total VOCs $1750 \mathrm{ppbC}$

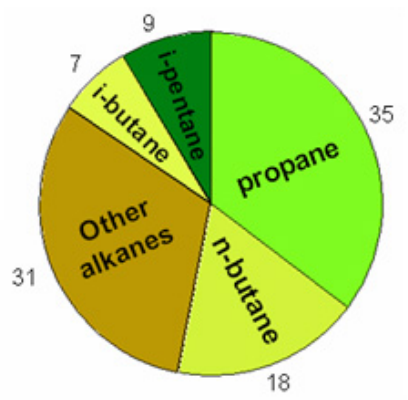

non-methane alkanes $1045 \mathrm{ppbC}$

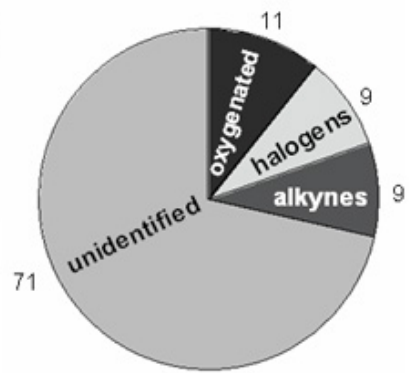

other \& unidentified VOCs $317 \mathrm{ppbC}$

Fig. 4. Average VOC distribution in urban sites by compound type during the morning period (6:00-9:00 AM). This distribution was obtained from the canister samples analyzed by GC-FID. Numbers around the circle charts indicate the percent contribution of each VOC species (species key: *2-methyl-1-butene, **1,2,4-trimethylbenzene) (Fig. by E. Velasco).

$426 \mathrm{~m}$ at La Merced) (Volkamer et al., 2005; Velasco et al., 2007). Intercomparison of all of these techniques was valuable for confirming the accuracy of each method and also to help identify the occurrence of short-term, highly fluctuating plumes of VOCs, which could be attributed to various small but intense point sources versus the occurrence of slowly varying levels of VOCs attributed to the mix of urban VOCs. Finally, an open-path FTIR system operated by UNAM (Grutter et al., 2005) obtained ambient concentration measurements for formaldehyde and a number of light alkanes.

\subsection{Key VOC results}

Results from these various VOC measurement methods provided the following key findings for VOCs in MCMA:

- Total non-methane hydrocarbon concentrations from urban sites during the morning rush hour period (6:009:00 h) averaged approximately $1.5 \mathrm{ppmC}$.

- The non-methane hydrocarbon burden in MCMA was dominated by alkanes (60\%), followed by aromatics $(15 \%)$ and olefins $(5 \%)$, based on ppbC. The remaining $20 \%$ were a mix of alkynes, halogenated hydrocarbons, oxygenated species, and other unidentified species (see
Fig. 4). This distribution is similar to that reported in earlier studies (Arriaga et al., 1997; Mugica et al., 2002), although it appears that the levels were slightly lower than in previous measurements, which may indicate that actions to control VOC emissions have been successful, despite the growth in the vehicular fleet and other activities (Velasco et al., 2007).

- Although differences were apparent among the different methods, these could be attributed to the different measurement perspectives (i.e., point vs. long-path, timeaveraged vs. short term) and, in general, there was good agreement among the different methods employed to measure VOCs.

- In terms of compound concentrations weighted by $\mathrm{OH}$ reactivity, the top five species were ethylene, propylene, propane, n-butane and m, p-xylene, while C4-C5 alkenes and toluene comprised the next five most reactive species in MCMA (Velasco et al., 2007).

- Elevated levels of toxic VOCs, including formaldehyde, acetaldehyde, 1,3-butadiene and the BTEX compounds (benzene, toluene, ethylbenzene and the xylene isomers), were frequently measured. 


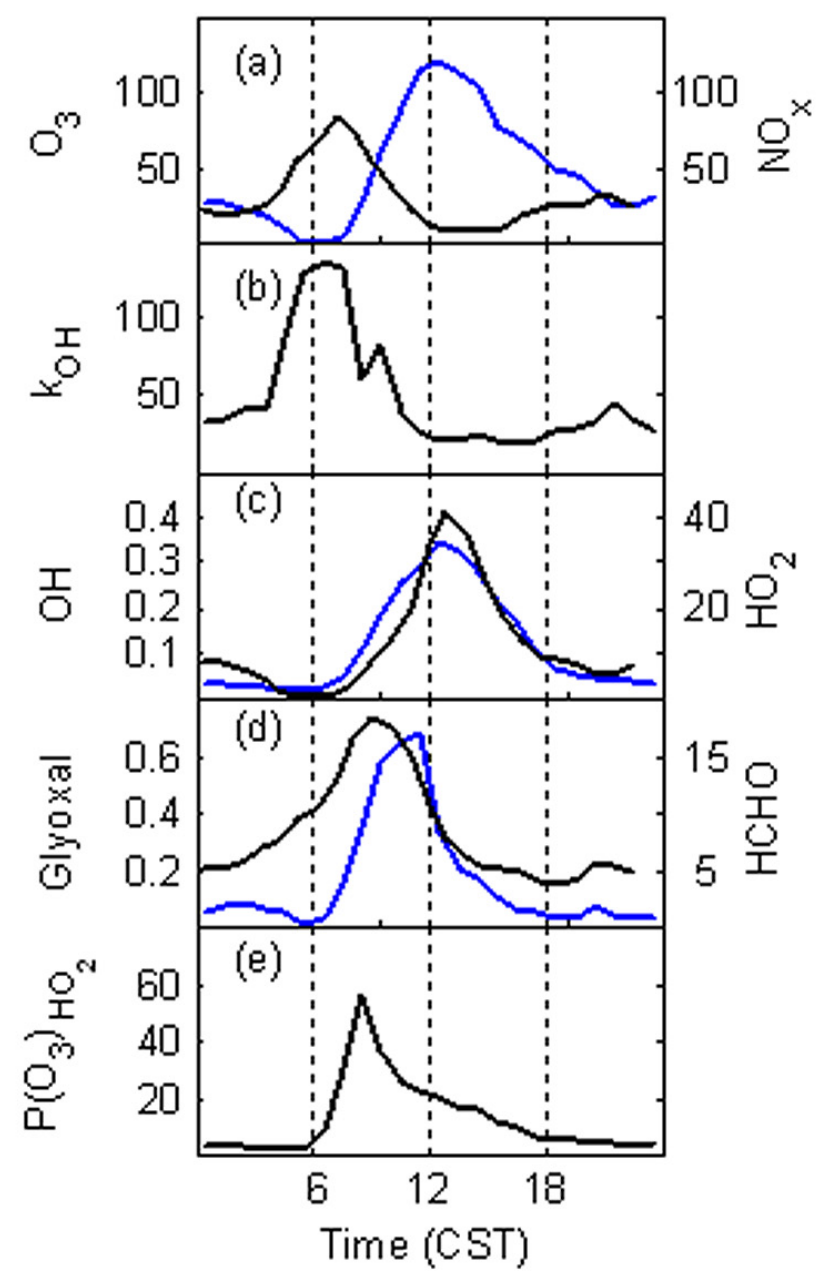

Fig. 5. Median diurnal variation of some photochemical variables in MCMA 2003: (a) $\mathrm{O}_{3}$ (ppbv, solid line), $\mathrm{NO}_{\mathrm{x}}$ (ppbv, dashed line, right axis); (b) $\mathrm{OH}$ reactivity, $\mathrm{k}_{\mathrm{OH}}\left(\mathrm{s}^{-1}\right)$; (c) $\mathrm{OH}$ (pptv, solid line), $\mathrm{HO}_{2}$ (pptv, dashed line, right axis); (d) glyoxal (ppbv, solid line), HCHO (ppbv, dashed line, right axis); and (e) ozone production from $\mathrm{HO}_{2}$ only, $\mathrm{P}\left(\mathrm{O}_{3}\right)_{\mathrm{HO}_{2}}$ (ppbv hr ${ }^{-1}$ ) (Fig. by W. H. Brune).

- Comparison of the morning ambient levels with the distribution of VOC species in a model-based 1998 EI suggested that the inventory under-estimates the contribution of some alkanes and over-estimates the contribution of some olefins and aromatics (Velasco et al., 2007).

- The VOC eddy covariance flux measurements provided new and valuable information to evaluate directly the local EI. Measured fluxes of olefins, toluene and acetone showed good agreement with the local model-based gridded 1998 EI (Velasco et al., 2005b).

- At the urban core, the ambient concentrations of VOCs depended strongly on the interaction of vehicular traffic and meteorological parameters. Weekly averages of the diurnal pattern of olefinic and aromatic VOC am- bient concentrations exhibited a strong peak during the morning rush hour with relatively low levels during the afternoon and evening.

- Comparisons between the ambient samples and the onroad samples showed that vehicle exhaust is the main source of many hydrocarbons, in particular, olefins and aromatics (Velasco et al., 2007).

- Glyoxal was successfully measured for the first time using a long-path DOAS instrument (Volkamer et al., 2005b). Results were used with CO measurements as an emission tracer to help assign sources of formaldehyde; these data indicated that primary formaldehyde emissions contribute $\sim 42 \%$, photochemical formation accounts for $\sim 38 \%$, and background levels constitute the remainder of $\sim 21 \%$ (Garcia et al., 2006).

\section{MCMA photochemistry}

The measurement suite deployed during MCMA-2003 enabled the most comprehensive study of the photochemistry in MCMA, or for that matter, any megacity in the developing world. In addition to the important distributed measurements of $\mathrm{NO}_{\mathrm{x}}$, VOCs, ozone, and aerosols, measurements were also made of radicals precursors like formaldehyde, the radicals hydroxyl $(\mathrm{OH})$, hydroperoxyl $\left(\mathrm{HO}_{2}\right)$, the oxidation intermediate glyoxal (CHOCHO), and the $\mathrm{OH}$ reactivity, the inverse of the OH lifetime (see Figs. 5 and 6). The most complete colocated measurement suite, including radical measurements, was at CENICA supersite; thus most of the following photochemistry discussion is based on analyses of the measurements at CENICA.

\subsection{Photochemical precursors}

The production of ozone and secondary organic aerosols (SOA) requires the presence of $\mathrm{NO}_{\mathrm{x}}$, VOCs, and sunlight. The median $\mathrm{NO}_{\mathrm{x}}$ was 86 ppbv during morning rush hour, although it exceeded $100 \mathrm{ppbv}$ on several days. In the afternoon, $\mathrm{NO}_{\mathrm{x}}$ was about 20 ppbv; at night, it was typically 20 $35 \mathrm{ppbv}$. In the morning (6:00 to 9:00 h) the average VOC concentration at urban sites was $1515 \mathrm{ppbC}, 2.3$ times higher than in the afternoon (Velasco et al., 2007). Compared to US cities, these $\mathrm{NO}_{\mathrm{x}}$ concentrations were about 2 times larger and the VOCs were 5 to 10 times larger (Shirley et al., 2006).

On average alkanes, alkenes, aromatics and aldehydes all contribute significantly to the $\mathrm{OH}$ reactivity (Lei et al., 2007). The measured $\mathrm{OH}$ reactivity had a large peak of $\sim 120 \mathrm{~s}^{-1}$ during morning rush hour, $25 \mathrm{~s}^{-1}$ during midday, and $\sim 35 \mathrm{~s}^{-1}$ at night. This diurnal behavior is similar to that of $\mathrm{NO}_{\mathrm{x}}$, which is consistent with a large transportation source of both $\mathrm{OH}$ reactivity and $\mathrm{NO}_{\mathrm{x}}$. Of the calculated contributions to the $\mathrm{OH}$ reactivity, $12 \%$ was due to $\mathrm{NO}_{\mathrm{x}}, 7 \%$ to $\mathrm{CO}, 4 \%$ to $\mathrm{HCHO}$ and $72 \%$ to VOCs (Shirley et al., 2006). 
The fractions are averages for all hours, day and night, over the campaign. These gaseous emissions are precursors for the large observed abundances of ozone, SOA, and other secondary pollutants observed in the MCMA, although not all of the photochemical conversion processes are fully understood at present. Measured MCMA OH reactivity is dramatically higher than those of typical U.S. cities, especially during the morning hours (Fig. 6).

High solar ultraviolet radiation fluxes, due to the MCMA's high altitude and low latitude, drive rapid photolysis, even in April. Typically April has been one of the MCMA's most polluted months, with high levels of all photochemically produced pollutants. In 2003, however, the unusually high humidity led to clouds and occasionally rain in the afternoon. This afternoon cloudiness often shut down the vigorous photochemistry, resulting in lower production of ozone and other secondary pollutants compared to other years. As a result, the median $\mathrm{MCMA} \mathrm{O}_{3}$ peaked at 115 ppbv near local noon at CENICA and never exceeded $150 \mathrm{ppbv}$. Other locales in the city experienced higher levels of ozone, but none exceeded 250 ppbv. These $\mathrm{O}_{3}$ abundances are lower than had been measured previously for April. While some of this decrease can be traced to the atypical cloudiness of April, the rest is likely due to efforts to reduce VOC emissions in the MCMA (Velasco et al., 2007).

\section{2 $\mathrm{HO}_{\mathrm{x}}$ production}

The radicals $\mathrm{OH}$ and $\mathrm{HO}_{2}$ displayed, as expected, strong diurnal behavior (Fig. 5). $\mathrm{OH}$ and $\mathrm{HO}_{2}$ together are called $\mathrm{HO}_{\mathrm{x}}$, of which $\mathrm{HO}_{2}$ is the dominant partner. $\mathrm{OH}$ was fairly consistent from day-to-day, with midday peak values of $0.25-0.4 \mathrm{pptv}\left((5-8) \times 10^{6} \mathrm{~cm}^{-3}\right)$. The effects of clouds on $\mathrm{OH}$ production could be seen in the reduction in $\mathrm{OH}$ on several afternoons. Variability was greater for $\mathrm{HO}_{2}$ than for OH. Peak $\mathrm{HO}_{2}$ varied from $15 \mathrm{pptv}\left(\sim 3 \times 10^{8} \mathrm{~cm}^{-3}\right)$ to $60 \mathrm{pptv}\left(\sim 12 \times 10^{8} \mathrm{~cm}^{-3}\right)$. The diurnal $\mathrm{HO}_{2}$ peak is narrower than the $\mathrm{OH}$ peak and is shifted one hour later. $\mathrm{HO}_{2}$ persisted at $\sim 5$ pptv ( 0.5 to 20 pptv) during the night. $\mathrm{HO}_{2}$ has a diurnal profile that peaked at $\sim 40 \mathrm{pptv}$ at 13:00, and decreased to less than 0.5 pptv at sunrise, when $\mathrm{HO}_{\mathrm{x}}$ production was just beginning to increase but when copious rush hour $\mathrm{NO}$ effectively scavenged $\mathrm{HO}_{2}$. The median $\mathrm{OH}$ peaks at $0.35 \mathrm{pptv}\left(\sim 7 \times 10^{6}\right) \mathrm{cm}^{-3}$ at local noon. The nighttime values ranged from $0.05 \mathrm{pptv}\left(\sim 1 \times 10^{6} \mathrm{~cm}^{-3}\right)$ to below the detection limit $\left(0.01\right.$ pptv or $\left.2 \times 10^{5} \mathrm{~cm}^{-3}\right)$. The median $\mathrm{HO}_{2}$ peaks at 37.2 pptv and falls off rapidly to less than a few pptv at night, with a minimum at morning rush hour, when $\mathrm{NO}$ is rapidly converting $\mathrm{HO}_{2}$ to $\mathrm{OH}$ and $\mathrm{NO}_{2}$ is rapidly converting $\mathrm{OH}$ to $\mathrm{HNO}_{3}$.

These MCMA $\mathrm{HO}_{\mathrm{x}}$ measurements are a good example of the buffering effects of the $\mathrm{OH}$ production and loss processes. Over the course of the study, $\mathrm{HO}_{2}$ peak values varied greatly from day-to-day, indicating dramatic changes in $\mathrm{HO}_{\mathrm{x}}$ sources, but $\mathrm{OH}$ peak values remained relatively unchanged.

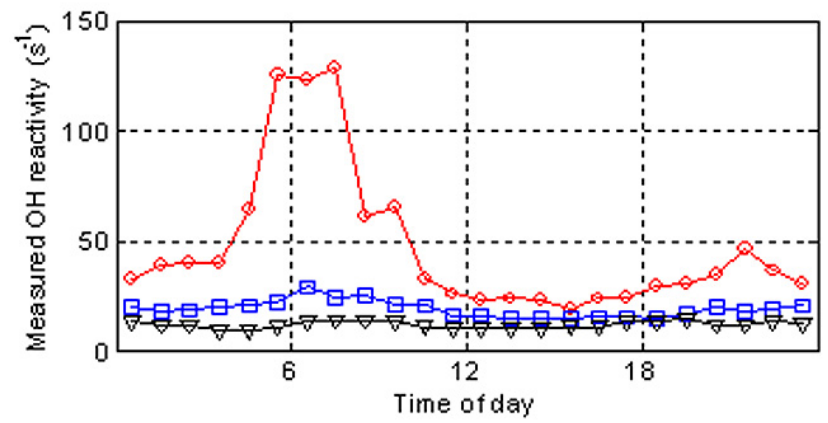

Fig. 6. The diurnal variation of median $\mathrm{OH}$ reactivity for three cities: Mexico City, April 2003 (red circles); New York City, August 2001 (blue squares); and Nashville, July 1999 (black triangles) (Fig. by W. H. Brune).

That $\mathrm{HO}_{2}$ is much more sensitive to $\mathrm{HO}_{\mathrm{x}}$ sources and sinks than $\mathrm{OH}$ suggests that $\mathrm{HO}_{2}$ must be measured along with $\mathrm{OH}$ to really test and understand the radical chemistry. As a result, the $\mathrm{OH}$ abundances in MCMA are similar to those in U.S. and European cities, while the $\mathrm{HO}_{2}$ is larger by a factor of two or more.

In a set of companion papers, Volkamer et al. (2007) and Sheehy et al. $\left(2007^{4}\right)$ use measurements of radical sources (i.e., $\mathrm{HONO}, \mathrm{HCHO}, \mathrm{O}_{3}$, J-values) and sinks (i.e., $\mathrm{VOC}$, $\mathrm{NO}$, $\mathrm{NO}_{2}$ ) to constrain the Master Chemical Mechanism to study the oxidative capacity of the atmosphere in terms of radical production and radical cycling. In Part 1, Volkamer et al. present a detailed analysis of $\mathrm{OH}, \mathrm{HO}_{2}$ and $\mathrm{RO}_{2}$ radical sources, which identifies the processing of alkenes as playing a major role in driving photochemical smog formation. In comparison to other urban airsheds, differences are identified in terms of the timing and magnitude of radical production. In Part 2, Sheehy et al. compare modeled concentrations of $\mathrm{HO}_{\mathrm{x}}$ to measurements by Shirley et al. (2006), and discuss the implications of observed differences in terms of VOC oxidation and ozone formation.

\subsection{Carbonyl precursors and products}

The large difference in $\mathrm{HO}_{2}$ results in part from the large difference in the $\mathrm{HO}_{\mathrm{x}}$ sources. Some of this difference is due to the greater photolysis frequencies, although the photolysis frequencies in MCMA are less than a factor of two larger than in US cities during their peak ozone months. Ozone, which was greater in MCMA than in US cities, contributes to the larger $\mathrm{HO}_{\mathrm{x}}$ sources in MCMA. However, a big difference was the greater amount of HCHO in MCMA. It peaks at $\sim 20 \mathrm{ppbv}$ in the morning (Volkamer et al., 2005b), represents about $40 \%$ of the $\mathrm{HO}_{\mathrm{x}}$ source, and was much larger in

\footnotetext{
${ }^{4}$ Sheehy, P. M., Volkamer, R. M., Molina, L. T., and Molina, M. J.: Oxidative Capacity of the Mexico City Atmosphere. Part 2: A radical recycling perspective, Atmos. Chem. Phys. Discuss., to be submitted, 2007.
} 
MCMA than in US cities during midday. An important question is the relative importance of the two HCHO sources: direct emission and photochemical production in the atmosphere (Garcia et al., 2006). During the midday, photochemical production appears to be $80 \%$ of the ambient $\mathrm{HCHO}$, while at night and in the early morning, primary production is $80 \%$ of the ambient $\mathrm{HCHO}$.

A major MCMA-2003 advance was the first detection of glyoxal (CHOCHO) in the atmosphere by DOAS (Volkamer et al., 2005b). Glyoxal is formed in the oxidation of several VOCs. It is produced during most of the day, although its abundance decreases after late morning due to greater photochemical loss. The atmospheric residence time of glyoxal with respect to photolysis and $\mathrm{OH}$-radical reaction is determined to be about $1.3 \mathrm{~h}$ for cloud-free skies at solar noon. Thus, time-resolved DOAS measurements of glyoxal indicate the rate of VOC oxidation in urban air and can be used to test predictions of photochemical smog formation by photochemical models.

\subsection{Photochemical results}

Several conclusions can be drawn from the analyses of these MCMA-2003 measurements:

- The distribution of photochemically active atmospheric constituents is uniform enough throughout the MCMA that results from the photochemistry studies at CENICA are likely to be applicable to all of the MCMA's urban core. The primary source of VOCs and $\mathrm{NO}_{\mathrm{x}}$ appears to be related to the vehicle exhaust, which is emitted across the MCMA (Velasco et al., 2007). More evidence comes from the good agreement between in situ and long-path DOAS measurements of $\mathrm{CO}, \mathrm{O}_{3}$, and $\mathrm{NO}_{2}$ at CENICA site, suggesting that the photochemistry is fairly uniform over the region sampled by DOAS (Dunlea et al., 2006, 2007).

- The combination of high $\mathrm{OH}$ reactivity, abundant sunlight and $\mathrm{NO}_{\mathrm{x}}$, and quite possibly, high levels of morning formaldehyde and acetaldehyde emissions jumpstarts the oxidation photochemistry during morning rush hour (Fig. 5). Ozone production rates exceeded $50 \mathrm{ppbv} \mathrm{hr}^{-1}$ beginning as early as an hour after sunrise (Shirley et al., 2006; Lei et al, 2007). This production is not detectable in the ozone measurements because the emitted NO rapidly depletes ozone to near zero ppbv, forming $\mathrm{NO}_{2}$ and then $\mathrm{HNO}_{3}$, even as ozone is being rapidly produced. Nonetheless, ozone increases rapidly throughout the morning, peaking near midday. The observed rapid formation of glyoxal shortly after sunrise indicates an efficient VOC oxidation process during morning hours (Volkamer et al., 2005). Oxidized SOA forms faster, i.e., simultaneously with glyoxal, and in about an order of magnitude larger amounts than expected (Volkamer et al., 2006). The rapid formation of nitric acid $\left(\mathrm{HNO}_{3}\right)$ is consistent with the increase in nitrate in the particles through the morning, suggesting that about $1 / 3$ of the $\mathrm{HNO}_{3}$ goes to the particle phase (Salcedo et al., 2006).

- Even in an environment with such high loadings of $\mathrm{NO}_{\mathrm{x}}$ and VOCs, steady-state photochemical models are generally able to simulate the median measured $\mathrm{OH}$ and $\mathrm{HO}_{2}$ (Shirley et al., 2006). The measured $\mathrm{OH}$ and $\mathrm{HO}_{2}$ tend to be $\sim 10 \%$ larger than the model during morning rush hour and 30\% smaller at midday; but these differences are within the uncertainties of the measurements and models. The agreement between the measured and modeled $\mathrm{HO}_{\mathrm{x}}$ is as good as or better than that obtained in other urban environments.

- A surprising result is the good agreement between the $\mathrm{HO}_{2} / \mathrm{OH}$ ratio as a function of $\mathrm{NO}$ that is measured and the ratio from a measurement-based steady-state model and a photochemical point model, although the measured ratio is two times greater than the steady-state analysis ratio when NO exceeds 20 ppbv (Shirley et al., 2006). This agreement is better than has been seen in any other environment where NO exceeded a few ppbv. In other urban areas, the observed $\mathrm{HO}_{2} / \mathrm{OH}$ ratio is roughly five to twenty times the steady-state analysis ratio for $\mathrm{NO}$ exceeding $10 \mathrm{ppbv}$. The difference between these other urban areas and MCMA is not particularly the $\mathrm{NO}_{\mathrm{x}}$ abundance, which is similar to some large US cities, but is instead the large amounts of VOCs that lead to high $\mathrm{OH}$ reactivities. A comparison of measured diurnal $\mathrm{OH}$ reactivity for MCMA-2003 with those measured in two US cities is shown in Fig. 6.

- Chemical transport model calculations indicate that ozone production is VOC-limited throughout the afternoon (Lei et al., 2007; Tie et al., 2007), in contrast to previous modeling studies indicating that ozone formation is $\mathrm{NO}_{\mathrm{x}}$-limited in MCMA (Molina et al., 2002). Because of the relatively high VOC-to- $\mathrm{NO}_{\mathrm{x}}$ ratios, the ozone production efficiency (i.e., $\mathrm{O}_{3}$ produced per $\mathrm{NO}_{\mathrm{x}}$ oxidized) is 4-10, larger than in U.S. cities where OPE is typically 3 to 8 (Lei et al., 2007); this difference is due to the higher abundance of VOCs in MCMA. Thus, despite the much higher abundances of VOCs in MCMA than in US cities, the sensitivities of ozone production to $\mathrm{NO}_{\mathrm{x}}$ and VOCs are generally qualitatively the same for MCMA and U.S. cities.

These conclusions and others are described in more detail in the cited accompanying papers and in cited papers that have been published in other journals. Ongoing analyses of this rich data set will undoubtedly lead to additional new conclusions about MCMA's photochemistry. In total, these conclusions provide scientific guidance for crafting regulatory strategies to continue the improvement of MCMA air quality. 


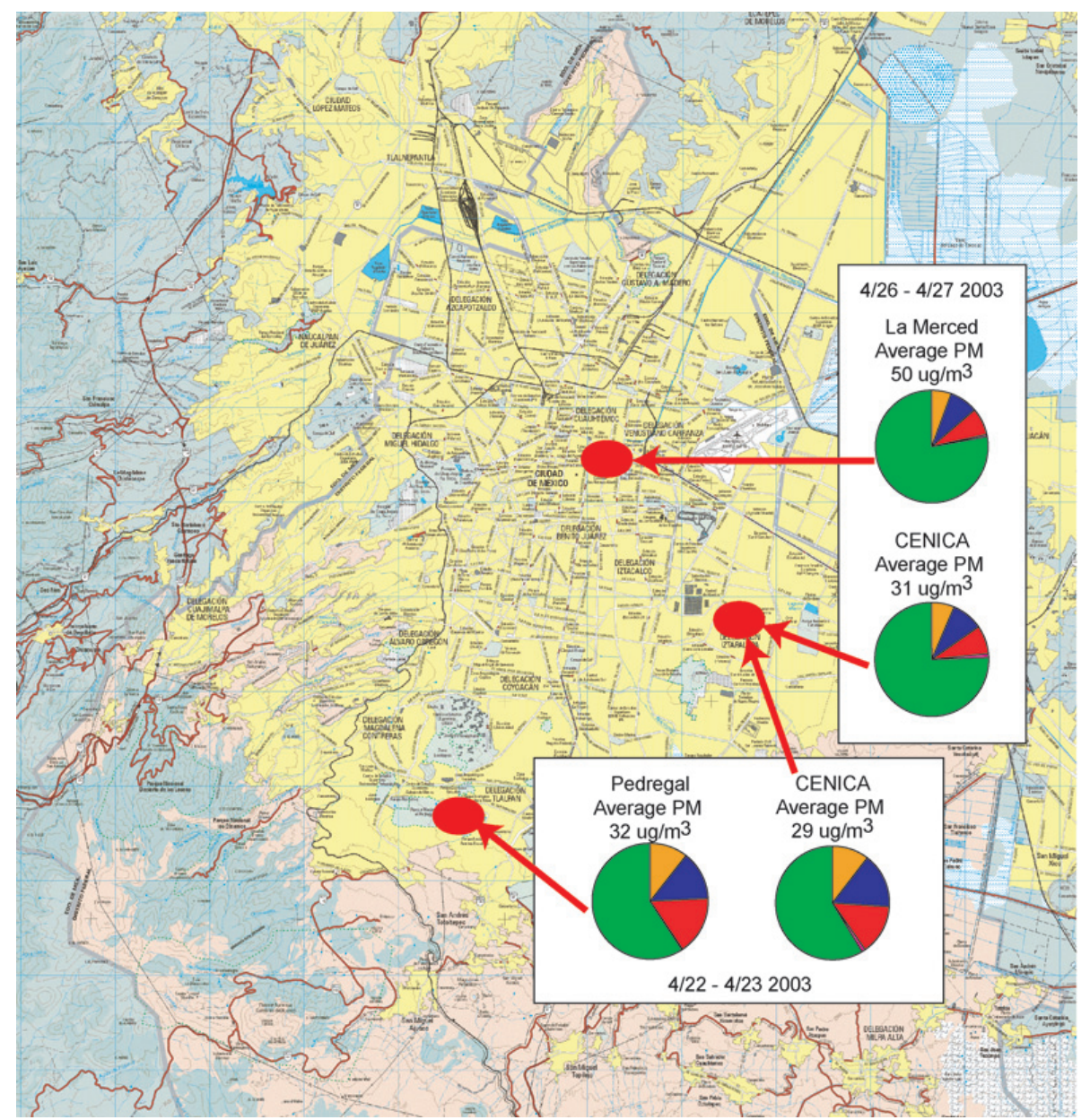

Fig. 7. The ambient non-refractory PM1 chemical composition (green/organic, red/sulfate, blue/nitrate, yellow/ammonium) was fairly consistent throughout the urban region of the MCMA for any given day during MCMA-2003, suggesting widespread sources of precursors and efficient secondary aerosol formation (Fig. by T. B. Onasch).

\section{MCMA particulate matter}

Particulate matter (PM) is important because of serious effects on human health, visibility, climate, and deposition of acid, toxics, and nutrients to ecosystems. PM is typically measured with different size cuts, e.g., $\mathrm{PM}_{10}, \mathrm{PM}_{2.5}$, and $\mathrm{PM}_{1}$ refer to all particles smaller than or equal to $10,2.5$, and $1 \mu \mathrm{m}$ respectively, with $\mathrm{PM}_{2.5}$ and smaller referred to as "fine particles" and larger particles are termed "coarse particles."

\subsection{MCMA PM instrumentation}

The MCMA-2003 Campaign included a state-of-the-art set of fine particle measurements, with less emphasis on coarse particles. The higher chemical, time, and size resolution of some of the techniques used during MCMA-2003, including the first use of aerosol mass spectrometry (AMS) and single particle soot photometry (SP2) in the city, allowed for a more detailed study of several aerosol components. As with other instrumentation the epicenter of the deployment was the CENICA supersite, but several instruments were deployed at other fixed sites and in the ARI mobile laboratory during both the 2002 exploratory measurements and the 2003 campaign (Kolb et al., 2004). In addition, the deployment of fine particle sampling systems at CENICA and aboard the ARI laboratory allowed detailed post analyses of a range of primary and secondary PM using a variety of advanced instrumental techniques.

\subsection{MCMA PM findings}

Comparing mobile laboratory data from different MCMA locations, the PM concentrations and properties measured at CENICA are generally representative for the MCMA. The following conclusions can be drawn:

- The average $\mathrm{PM}_{2.5}$ concentration was $\sim 36 \mu \mathrm{g} \mathrm{m}^{-3}$, with maximum hourly averaged concentrations exceeding $100 \mu \mathrm{g} \mathrm{m}^{-3}$ on several occasions (Salcedo et al., 
2006). These levels are similar to those observed in the Eastern part (inland/downwind) of the Los Angeles basin (Hughes et al., 2000; Sardar et al., 2005), about twice as large as those observed in urban locations in the Eastern US (Zhang et al., 2005a; Drewnick et al., 2004), and similar to or smaller than those reported at other developing world megacities such as Mumbai, Delhi, and Beijing (Kumar and Joseph, 2006; Laakso et al., 2006).

- Carbonaceous (organic and black carbon) species dominated the fine particle concentration during MCMA2003 with $2 / 3$ of the mass, with the remaining $1 / 3$ accounted for by inorganic and crustal species (Salcedo et al., 2006). The concentrations and compositions are consistent at various locations within the city (see Fig. 7), suggesting widespread sources of precursors and efficient secondary aerosol formation.

- Biomass burning made a significant contribution to organic aerosols in the later part of the campaign (after $\sim 21$ April) (Salcedo et al., 2006), when regional fire activity increased substantially (C. Wiedinmyer, NCAR, personal communication, 2004). A substantially larger concentration of organic aerosols $(\times 1.9)$ was observed during that period, along with smaller increases for crustal material $(\times 1.5)$ and black carbon $(\times 1.3)$, while the levels of non-refractory inorganic species did not increase. Since some of these differences could also be due to differences in meteorology and emissions during the two periods, the direct quantification of the biomass burning contribution to carbonaceous aerosols remains a subject of active research using both ${ }^{14} \mathrm{C}$ measurements (Marley et al., 2007b $\mathrm{b}^{5}$ ) and positive matrix factorization (PMF) analysis of AMS spectra (Ulbrich et al., 2006).

- Particle species are typically categorized as "primary" if they are emitted in the particle phase and "secondary" if they are emitted in the gas-phase and subsequent chemical reactions bring them to the particle phase. Measurements from several instruments (Salcedo et al., 2006; Volkamer et al., 2006; Johnson et al., 2006) and the recently developed analysis techniques of Zhang et al. $(2005 \mathrm{~b}, \mathrm{c})$ can be used to apportion the total measured mass to these components. Using the data from the first half of the campaign to exclude periods with potentially strong influence from regional biomass burning, secondary species created in the intense photochemistry of MCMA comprise the majority $(\sim 2 / 3)$ of the fine PM mass, led by secondary organic aerosol (SOA, $\sim 31 \%$ of mass), and followed by the secondary inorganic species sulfate, nitrate, ammonium,

\footnotetext{
${ }^{5}$ Marley, N. A., Gaffney, J. S., Sturchio, N. C., Guilderson, T., Rowe, M., Steelman, K. L., and MacMillan, A.: Evidence for biomass and regional source contributions to aerosol absorption in Mexico City during MCMA 2003, in preparation, 2007b.
}

and chloride $(12 \%, 12 \%, 7 \%$, and $1 \%$ respectively). Primary species are responsible for the remaining $1 / 3$ of the mass, comprised of primary organic aerosols (POA, $\sim 20 \%$ ), black carbon (BC, 10\%), and crustal material $(6 \%)$. The size distributions were dominated by a prominent accumulation mode where inorganic and organic species appeared to be internally mixed most of the time, and a smaller externally-mixed organic mode likely related to traffic emissions. Rapid growth of the smaller mode due to condensation of secondary species was observed (Salcedo et al., 2006).

- The total concentrations, species fractions, and diurnal cycles observed are generally consistent with the results of the 1997 IMADA-AVER campaign (Salcedo et al., 2006; Chow et al., 2002).

- SOA is dominated by anthropogenic precursors and is formed almost an order of magnitude more efficiently than state-of-the-art models predict. This higher efficiency is already observed shortly after sunrise, with a significant contribution of first generation products. The main pathways of SOA formation in urban areas are currently unaccounted for, which has important implications for global climate and air quality (Volkamer et al., 2006). The amount of SOA increased as the air was advected away from the city center, consistent with its rapid formation (Onasch et al., 2004).

- The levels of black/elemental carbon have not changed significantly since the 1997 IMADA-AVER campaign, consistent with a lack of control strategies for this component. The MCMA remains a large source of BC to the regional environment (Marley et al., 2007a; Baumgardner et al., 2007). Vehicle traffic was responsible for a significant fraction of the POA and BC emissions (Jiang et al., 2006; Salcedo et al., 2006; Baumgardner et al., 2007). Freshly-emitted particles containing BC were fractal but during the day were rapidly coated $(\sim$ a few hrs) by secondary species (inorganic and organic) leading to internally mixed particles and transforming them into more compact shapes (Johnson et al., 2005; Salcedo et al., 2006; Baumgardner et al., 2007). Two studies have analyzed the light absorption efficiency of $\mathrm{BC}$ particles during the campaign (Barnard et al., 2007; Baumgardner et al., 2007).

- Polycyclic aromatic hydrocarbons (PAHs) are highly mutagenic (Hannigan et al., 1998; Evans et al., 2002) and carcinogenic (Denissenko et al., 1996) products of incomplete combustion, and are thought to be important for health effects even though they represent only a fraction of a percent of the ambient particle mass. MCMA2003 was the first campaign in which three independent methods were used to measure particle-bound PAHs leading to a number of insights on both PAH concentrations and the techniques themselves (Marr et al., 2006; 
Dzepina et al., 2007). Peak concentrations of PAHs were reached during the morning rush hour and were of the order of $120 \mathrm{ng} \mathrm{m}^{-3}$, which is higher than in US cities (Marr et al., 2004). Motor vehicles were found to be a significant source of PAHs, with $20 \%$ of the vehicles accounting for $50 \%$ of the emissions (Jiang et al., 2005), while garbage and biomass burning were also sources of these species. Photoelectric measurements (PAS) detect a very rapid decay of surface PAHs in the morning photochemistry, which may be due to surface reactions of the PAHs and/or to coating of the particles with secondary species that reduce the response of the instrument (Marr et al., 2006; Baumgardner et al., 2006). Very reactive and toxic PAHs such as cyclopenta $[c d]$ pyrene may be present in significant concentrations in the MCMA atmosphere and may be missed by traditional sampling techniques due to filter reaction artifacts (Dzepina et al., 2007).

- The main inorganic aerosol species were $\mathrm{NH}_{4} \mathrm{NO}_{3}$, $\left(\mathrm{NH}_{4}\right)_{2} \mathrm{SO}_{4}, \mathrm{NH}_{4} \mathrm{HSO}_{4}$, and $\mathrm{NH}_{4} \mathrm{Cl}$. The high local emissions of $\mathrm{NH}_{3}$ facilitated the formation of the more volatile nitrate and chloride species. The inorganic acids were neutralized by $\mathrm{NH}_{4}^{+}$most of the time, although during some periods fine particles had an $\mathrm{NH}_{4}^{+}$ deficit and were thus more acidic. Nitrate was formed from the reaction of $\mathrm{NH}_{3}$ with locally-formed $\mathrm{HNO}_{3}$. In the morning about $1 / 3$ of the $\mathrm{HNO}_{3}$ formed in the gas-phase condensed onto the particles. Sulfate formation is slower and occurred over more regional scales. The concentrations of $\mathrm{NH}_{4} \mathrm{Cl}$ were generally low with a diurnal cycle consistent with the semi-volatile character of this species. However, short-lived ( $\sim 15 \mathrm{~min}$ ) plumes of up to $39 \mu \mathrm{g} \mathrm{m}^{-3}$ of $\mathrm{NH}_{4} \mathrm{Cl}$ were detected at CENICA and other locations in the city, the origin of which remains under investigation (Salcedo et al., 2006).

- The concentrations of the inorganic aerosol species and their precursor gas-phase species were consistent with an inorganic aerosol model (ISORROPIA) during most periods. The model predicted up to several ppb of gasphase $\mathrm{HCl}$ during some periods (this species was not measured directly). The importance of the $\mathrm{Cl}$ radical to MCMA photochemistry appears to be very small, although the subject deserves further investigation since this chemistry cannot be fully constrained without measuring additional species (San Martini et al., 2006a, b). Inorganic PM modeling of the MCMA-2003 data (San Martini et al., 2006a,b) results in fewer discrepancies with the data than those from previous campaigns (Moya et al., 2001; San Martini et al., 2005), likely due to the higher time resolution and reduced artifacts of the 2003 data and the lower influence of crustal species during MCMA-2003.
- The most abundant refractory elements and metals were $\mathrm{Si}, \mathrm{K}, \mathrm{Fe}, \mathrm{Ca}$, and $\mathrm{Al}$. A positive matrix factorization (PMF) analysis of these data concluded that the main sources of these elements were industries in the northern part of the city, wind-blown soil, and biomass burning. The results for the first two sources are consistent with previous studies of refractory species in the MCMA, while the contribution of biomass burning to these elements had not been clearly identified before (Johnson et al., 2006).

- The vertical distribution of aerosols and ozone were studied with two LIDAR instruments (Ristori et al., 2004; Frey et al., 2004). Both pollutants were wellmixed in the boundary layer (BL) during the day, which reached heights of up to $4 \mathrm{~km}$ above ground. A residual layer above $1 \mathrm{~km}$ was observed in some days due to detachment of the top of the boundary layer, which could be re-entrained during BL growth in the next day.

- Intense new particle formation (NPF) and growth was observed both in the southern boundary of the Mexico City basin (Santa Ana Tlacotenco) and at the CENICA supersite. It correlated with $\mathrm{SO}_{2}$ plumes, suggesting the involvement of $\mathrm{H}_{2} \mathrm{SO}_{4}$ (Dunn et al., 2004; Salcedo et al., 2006), as is the case at many other locations (Kulmala et al., 2004). Inside the city NPF was favored when preexisting particle surface area was low (Dunn et al., 2004), again consistent with observations at other locations (McMurry et al., 2005).

- The composition of ultrafine particles was studied at the CENICA supersite when a nano-SMPS (Dunn et al., 2004) and AMS (Salcedo et al., 2006) overlapped. Figure 8 shows the number size distribution function and composition of overlapping size ranges from these two instruments. Three types of events were observed. (a) Every morning during the rush hour high number concentrations of particles with $d_{m}>10 \mathrm{~nm}$ were observed, whose composition was dominated by hydrocarbonlike organics (HOA, a surrogate for POA (Zhang et al., 2005b,c)). These particles are dominated by traffic exhaust as observed elsewhere (e.g., Zhang et al., 2004). (b) One strong new particle formation event was observed in the afternoon of May 3 (Dunn et al., 2004), which was the only time during this period in which particles with $d_{m}<10 \mathrm{~nm}$ reached high concentrations. The composition of the particles growing from this event was dominated by sulfate and ammonium, with a smaller amount of oxygenated organics (OOA, typically a surrogate for SOA (Zhang et al., 2005b, c)), which is consistent with the involvement of sulfuric acid in the growth of particles following nucleation and similar to results obtained from detailed analyses of similar events in Pittsburgh (Zhang et al., 2004). (c) Another event with elevated sulfate, ammonium, nitrate, 
and OOA was observed in the previous day, which potentially was due to the growth (by condensation of secondary species) of new particles that had nucleated upwind of the CENICA site (Salcedo et al., 2006; Zhang et al., 2004).

\section{Instrumentation advances}

The deployment of a significant number of advanced instruments, many operating with real-time $(\sim 1 \mathrm{~s})$ response times, along with a large number of established air quality monitoring instruments at the CENICA supersite, at the La Merced monitoring site and onboard the ARI mobile laboratory provided significant opportunities to intercompare and evaluate a number of instruments in a highly polluted environment. A number of papers documenting and/or cross comparing the performance of instruments have been based on MCMA2003 measurements.

\subsection{Gas phase instruments}

A novel fast gas chromatograph/luminal chemiluminescence instrument designed to detect nitrogen dioxide and peroxyacetyl nitrate (PAN) was developed at ANL and deployed at both the CENICA supersite and on the ARI mobile laboratory (Marley et al., 2004). Cross comparisons of $\mathrm{NO}_{2}$ with long-path DOAS and co-located point TILDAS instruments showed good agreement. Comparisons between MCMA PAN measurements made with an earlier version fielded in 1997 and the more recent 2003 version are presented in a second paper (Marley et al., 2007a).

Intercomparison measurements between standard ultraviolet absorption ozone monitors and open path DOAS and FTIR spectroscopic measurements by Dunlea et al. (2006) revealed discrepancies that are most likely due calibration errors, while unexpected excursions of an $\mathrm{O}_{3}$ monitor on-board the ARI mobile laboratory were correlated with primary PM emissions, suggesting failure of the instrument's fine PM filter. Standard chemiluminescence (CL) $\mathrm{NO}_{\mathrm{x}}$ monitor measurements of $\mathrm{NO}_{2}$ were compared with co-located TILDAS $\mathrm{NO}_{2}$ measurements, revealing very large over measurements for the CL instrument during periods of active photochemistry (Dunlea et al., 2007). The errors in the CL measurements are consistent with the reduction of additional nitrogen oxide species other than $\mathrm{NO}_{2}$ on its molybdenum oxide catalyst. This interference correlates well with non- $\mathrm{NO}_{\mathrm{x}}$ reactive nitrogen species $\left(\mathrm{NO}_{\mathrm{z}}\right)$ as well as with ambient $\mathrm{O}_{3}$ concentrations, indicating a photochemical source for the interfering species. A combination of ambient gas phase nitric acid and alkyl nitrates is deduced to be the primary cause of the interference.

In addition to performing ground breaking open path FTIR ambient measurements at La Merced (Grutter et al., 2005),
Grutter and co-workers also demonstrated the utility of making high time resolution measurement of both criteria and non-criteria gaseous exhaust emissions during vehicle dynamometer tests, demonstrating the technique on an ultralow emission hybrid vehicle (Reyes et al., 2006).

\subsection{PM instrumentation}

The MCMA-2003 campaign was one of the first to field two Aerodyne AMS instruments, one at the CENICA supersite and the second on-board the ARI mobile laboratory. The AMS relies on a supersonic nozzle and lens system to form ambient submicron particles into a narrow particle beam that can be directed into the mass spectrometric detection region. AMS laboratory studies had clearly indicated that nonspherical solid particles, like ammonium sulfate, focused less tightly than spherical liquid or solid particles (Jayne et al., 2000; Huffman et al., 2005). It was necessary to show that real atmospheric particles did not focus poorly enough that a significant fraction failed to enter the AMS's detection region. During MCMA-2003 both AMS units were outfitted with an automated beam width probe (BWP) that could be used to profile the particle beam width by systematically attenuating the particle beam while the mass spectrometer monitored various PM components (Salcedo et al., 2007). The BWPs on both AMS units showed that all major species in MCMA accumulation mode PM exhibited the same beam profiles, indicating that these particles were internally mixed most of the time, although some smaller mode particles, characteristic of primary combustion exhaust particles, exhibited different beam profiles than accumulation-mode organic and inorganic (ammonium/sulfate/nitrate) species. The BWP measurements did demonstrate that no substantial portion of the MCMA fine particles were poorly focused enough to miss the AMS detection region.

While the AMS detects non-refractory PM species as a function of fine particle size, it does not directly detect their black carbon component. As noted above in Section 7, coincident with the MCMA-2003 Campaign, Baumgardner et al. (2007) measured MCMA fine PM mass concentrations of elemental carbon (EC), particle by particle, over a full eight day period using an innovative laser-induced incandescence (LII) based SP2 instrument.

Finally, two innovative LIDAR systems designed to measure both PM and ozone vertical profiles, were deployed during MCMA-2003. A tunable ultraviolet differential absorption LIDAR (DIAL) instrument supplemented by a $532 \mathrm{~nm}$ elastic scatter LIDAR was fielded by the EPFL and a compact Raman LIDAR was fielded by MIT and FUB. While a detailed comparison of data from these two CENICA located systems has not yet been published, preliminary descriptions of the instruments and sample MCMA data have been published in symposium proceedings (Ristori et al., 2004; Frey et al., 2004). 


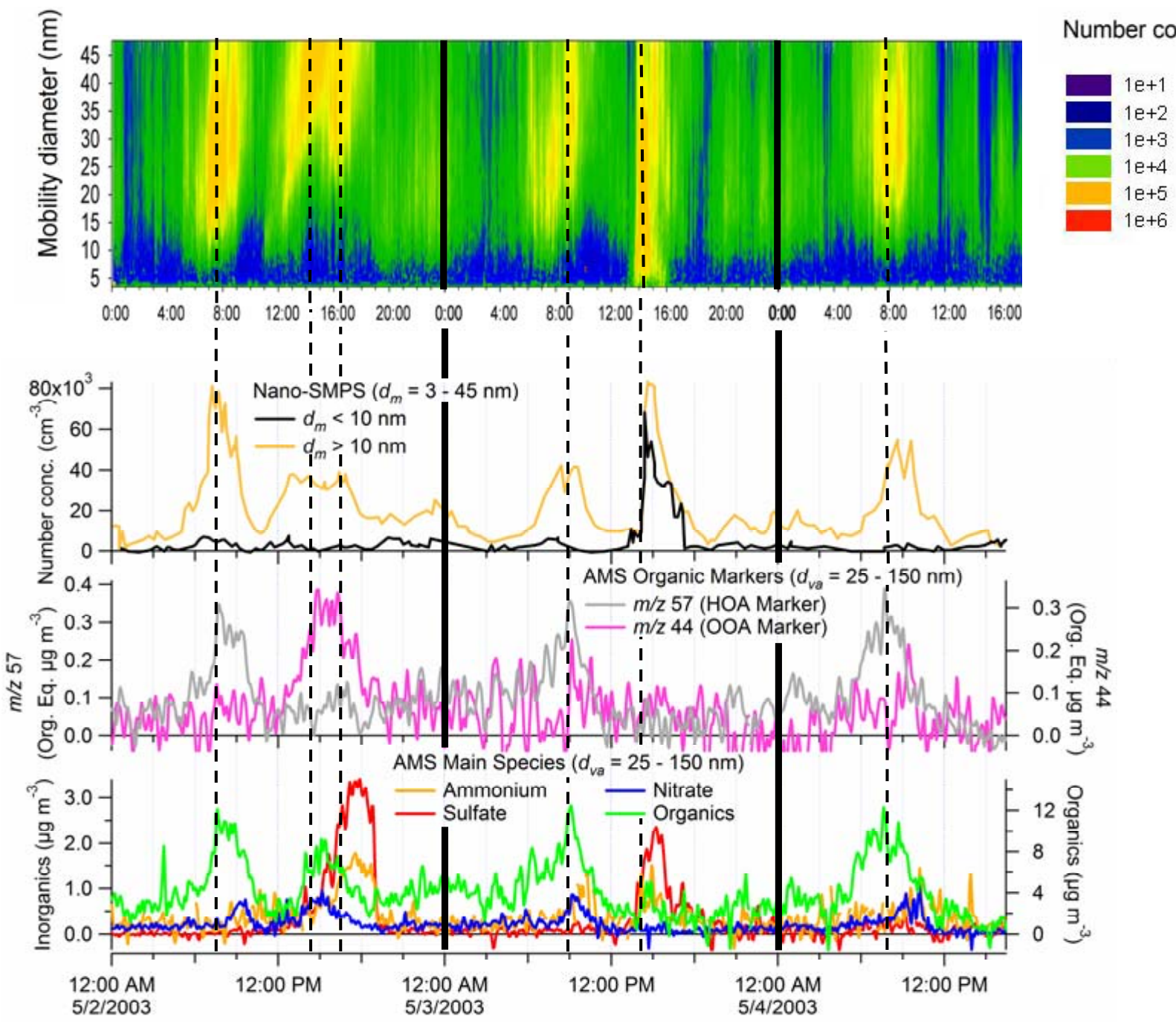

Fig. 8. Measurements of ultrafine particles at the CENICA Supersite for a 3-day period (2-4 May 2003). Top: number size distribution function measured with a nano-SMPS. Upper-middle: integrated number concentrations above and below $10 \mathrm{~nm}$ mobility diameter $\left(d_{m}\right)$. Lower-middle: signals of AMS markers of oxygenated and hydrocarbon-like organic aerosols (HOA and OOA, (Zhang et al., 2005bc)) in particles smaller than $150 \mathrm{~nm}$ vacuum aerodynamic diameter $\left(d_{v a}\right)$. Bottom: concentrations of main AMS species for $d_{v a}<150 \mathrm{~nm}$. Thick vertical lines indicate midnight, and dashed lines correspond to the periods with the highest concentrations of ultrafine particles identified by the nano-SMPS. The relationship between $d_{m}$ and $d_{v a}$ depends on particle density and shape as described by DeCarlo et al. (2004). When particles are growing the nano-SMPS detects them earlier due to its lower size limit. The AMS data includes larger sizes for improved signal-to-noise, but the composition is similar to that of the smaller particles detected (Fig. by K. Dzepina).

\section{Summary}

Following exploratory measurements in 2002, the MCMA2003 Campaign was designed to investigate the extremely vigorous atmospheric photochemistry of North America's most populous metropolitan area. MCMA-2003 enlisted over 100 scientists from 30 institutions in 5 countries. In this paper we have summarized the findings they have published to date.

Meteorological observations and correlated mesoscale modeling activities were able to establish that a small number of typical early spring meteorological episodes led to characteristic distributions of photochemical pollutants within the MCMA basin. Models also supported observations that under most conditions, pollutant export from the basin is relatively rapid and that pollutant carryover from day to day is not a major factor in the valley's photochemistry.

Emissions studies confirmed that motor vehicles play a major role in supplying the $\mathrm{NO}_{\mathrm{x}}$ and VOC precursors that fuel MCMA's extremely active photochemistry. Both onroad $\mathrm{HCHO}$ vehicle emissions measurements and correlation of ambient $\mathrm{HCHO}$ concentrations with $\mathrm{CO}$, a combustion 
emission tracer, and $\mathrm{HCOHCO}$, a photochemistry tracer, illustrated the strong impact of direct $\mathrm{HCHO}$ emissions on this key photochemical radical source and air toxic species. MCMA motor vehicles were also shown to produce copious amounts of primary PM elemental carbon and particle bound PAHs, $\mathrm{CO}$, and a wide range of air toxics, including acetaldehyde, benzene, toluene, and xylenes, in addition to formaldehyde. Innovative eddy covariance measurements of selected VOC fluxes indicated that the MCMA emissions inventories for some VOC species are not as inaccurate as some prior studies have indicated.

While $\mathrm{NO}_{\mathrm{x}}$ levels are high, extremely large loadings of reactive VOCs were measured in the MCMA atmosphere. During the morning rush hours total VOC ambient loadings averaged approximately $1.5 \mathrm{ppmC}$. In general, VOC levels were typically 5 to 10 times higher than those measured in U.S. cities. Alkanes, alkenes and aromatics all contribute significantly to extremely high daytime $\mathrm{OH}$ reactivities.

While these extremely high $\mathrm{OH}$ reactivities keep MCMA midday $\mathrm{OH}$ concentrations within the high end of levels observed in other North American cities, very high midday $\mathrm{HO}_{2}$ concentrations result in extraordinary $\mathrm{HO}_{\mathrm{x}}$ levels. Another signature of MCMA photochemistry is its rapid onset driven primarily by the very high levels of reactive VOCs emitted by morning traffic. Ozone production rates exceeded $50 \mathrm{ppbv} \mathrm{hr}^{-1}$ beginning as early as an hour after sunrise.

Heavy fine particle haze is also a signature of MCMA photochemistry. MCMA $\mathrm{PM}_{2.5}$ concentration averaged $\sim 36 \mu \mathrm{g} \mathrm{m}^{-3}$, with maximum hourly averaged concentrations exceeding $100 \mu \mathrm{g} \mathrm{m}^{-3}$ on several occasions. Secondary organic aerosol was the major fine PM component during photochemical episodes. SOA formation is dominated by anthropogenic precursors and is formed almost an order of magnitude more efficiently than predicted by current models. The onset of very high efficiency SOA formation is observed shortly after sunrise, with a significant contribution from first generation products. Under some meteorological conditions biomass burning particles can also contribute significant fine PM.

MCMA-2003 produced very large and valuable data sets describing the chemical and physical properties of the city's reactive atmosphere. The papers cited here, many of which are part of this special issue, have already added significantly to our understanding of how photochemistry transforms the atmosphere of MCMA and similar megacities around the world. This information will improve significantly the scientific understanding that decision makers in Mexico will need to craft effective policies for protecting human health and ecosystem viability as well as provide insights to air pollution problems in other megacities around the world.

The experience and the key findings from MCMA-2003 Campaign provided the framework for planning MILAGRO (Megacity Initiative: Local and Global Research Observations), a massive, multi-component international collaborative scientific project designed to follow the long- range evolution of the MCMA urban plume that took place in March 2006. We anticipate that the MCMA-2003 data set, coupled with ongoing measurements and the comprehensive data set from MILAGRO, will continue to contribute to our understanding of megacity air pollution and its potential impacts on human health, ecosystem viability, and climate change on urban, regional, and even hemispheric scales.

Acknowledgements. This field campaign is the collaborative efforts of a large number of participants with the support of multi-national agencies. The MCMA-2003 participants would like to thank GDF-SMA, SEMARMAT, SEGEM for logistical support and to CENICA/INE for hosting the supersite. The MCMA-2003 participants are grateful for funding from the Mexican Metropolitan Environmental Commision (CAM), US National Science Foundation (NSF grants ATM-0308748, ATM-0511803, ATM-0528170, ATM-528227, ATM 0449815, ATM 0528634, ATM-0209972, ATM-308748), US Department of Energy Atmospheric Science Program (DOE grants DE-FG02-0563980, DE-FG02-05ER63981 and DE-RG02-05ER63982), the MIT Alliance for Global Sustainability and PEMEX. The authors would like to thank R. Volkamer, E. Velasco, M. Zavala, T.B. Onasch, X. Ren and K. Dzepina for their help in preparing the figures and reviewing the draft manuscript.

Edited by: U.Pöschl

\section{References}

Arriaga, J. L., Escalona, S., Cervantes, A. D., Orduñez, R., and Lopez, T.: Seguimiento de COV en aire urbano de la ZMCM 1992-1996, in: Contaminación Atmosférica, Vol. 2, edited by: Colin, L. G. and Varela, J. R., UAM, Mexico, 1997.

Arriaga-Colina, J. L., West, J. J., Sosa, G., Escalona, S. S., Orduñez, R. M., and Cervantes, A. D.: Measurements of VOCs in Mexico City (1992-2001) and evaluation of VOCs and CO in the emissions inventory, Atmos. Environ., 38, 2523-2533, 2004.

Baez, A. P., Belmont, R., and Padilla, H.: Measurements of formaldehyde and acetaldehyde in the atmosphere of Mexico City, Environ. Pollut., 89, 163-167, 1995.

Barnard, J. C., Kassianov, E. I., Ackerman, T. P., Johnson, K., Zuberi, B., Molina, L. T., and Molina, M. J.: Estimation of a "radiatively correct" black carbon specific absorption during the Mexico City Metropolitan Area (MCMA) 2003 field campaign, Atmos. Chem. Phys., 7, 1645-1655, 2007, http://www.atmos-chem-phys.net/7/1645/2007/.

Baumgardner, D., Kok, G. L., and Raga, G. B.: On the diurnal variability of particle properties related to black carbon in Mexico City, Atmos. Chem. Phys. Discuss., 7, 1623-1653, 2007, http://www.atmos-chem-phys-discuss.net/7/1623/2007/.

Bishop, G. A., Stedman, D. H., de la Garza, J., and Davalos, F.: On road remote sensing of vehicle emissions in Mexico, Environ. Sci. Technol., 31, 3505-3510, 1997.

Blake, D. R. and Rowland, F. S.: Urban leakage of liquefied petroleum gas and its impact on Mexico City air quality, Science, 269, 953-956, 1995.

CAM: Inventario de emisiones a la atmósfera, Zona Metropolitana del Valle de México, 1998, Comisión Ambiental Metropolitana, Mexico, 2001. 
CAM: Programa para Mejorar la Calidad del Aire en el Valle de México 2002-2010, Comisión Ambiental Metropolitana, Mexico, 2002.

CAM: Inventario de emisiones a la atmósfera, Zona Metropolitana del Valle de México, 2002, Comisión Ambiental Metropolitana, Mexico, 2004.

CAM: Inventario de emisiones a la atmósfera, Zona Metropolitana del Valle de México 2004, Comisión Ambiental Metropolitana, Mexico, 2006.

Chow, J. C., Watson, J. G., Edgerton, S. A., and Vega, E.: Chemical composition of $\mathrm{PM}_{2.5}$ and $\mathrm{PM}_{10}$ in Mexico City during winter 1997, Sci. Total Environ., 287, 177-201, 2002.

DeCarlo, P., Slowik, J. G., Worsnop, D. R., Davidovits, P., and Jimenez, J. L.: Particle morphology and density characterization by combined mobility and aerodynamic diameter measurements. Part 1: Theory, Aerosol Sci. Technol., 38, 1185-1205, doi:10.1080/027868290903907, 2004.

Decker, E. H., Elliot, S., Smith, F. A., Blake, D. R., and Rowland, F. S.: Energy and material flow through the urban environment, Ann. Rev. Energy Environ., 25, 685-740, 2000.

de Foy, B., Caetano, E., Magana, V., Zitacuaro, A., Cardenas, B., Retama, A., Ramos, R., Molina, L. T., and Molina, M. J.: Mexico City basin wind circulation during the MCMA-2003 Field Campaign, Atmos. Chem. Phys., 5, 2267-2288, 2005, http://www.atmos-chem-phys.net/5/2267/2005/.

de Foy, B., Clappier, A., Molina, L. T., and Molina, M. J.: Distinct wind convergence patterns in the Mexico City basin due to the interaction of the gap winds with the synoptic flow, Atmos. Chem. Phys., 6, 1249-1265, 2006a.

de Foy, B., Molina, L. T., and Molina, M. J.: Satellite-derived land surface parameters for mesoscale modeling of the Mexico City basin, Atmos. Chem. Phys., 6, 1315-1330, 2006 b.

de Foy, B., Varela, J. R., Molina, L. T., and Molina, M. J.: Rapid ventilation of the Mexico City basin and regional fate of the urban plume, Atmos. Chem. Phys., 6, 2321-2335, 2006c.

de Foy, B., Lei, W., Zavala, M., Volkamer, R., Samuelson, J., Mellqvist, J., Galle, B., Martinez, A. P., Grutter, M., and Molina, L. T.: Modelling constraints on the emission inventory and on vertical diffusion for $\mathrm{CO}$ and $\mathrm{SO}_{2}$ in the Mexico City Metropolitan Area using solar FTIR and zenith sky UV spectroscopy, Atmos. Chem. Phys., 7, 781-801, 2007,

http://www.atmos-chem-phys.net/7/781/2007/.

Denissenko, M. F., Pao, A., Tang, M., and Pfeifer, G. P.: Preferential formation of benzo[a]pyrene adducts at lung cancer mutational hotspots in P53, Science, 18, 430-432, 1996.

Doran, J. C. and Zhong, S.: Thermally driven gap winds into the Mexico City basin, J. Appl. Meteorol., 39, 1330-1340, 2000.

Doran, J. C., Abbott, S., Archuleta, J., Bian, X., Chow, J., Coulter, R. L., de Wekker, S. F. J., Edgerton, S., Elliott, S., Fernandez, A., Fast, J. D., Hubbe, J. M., King, C., Langley, D., Leach, J., Lee, J. T., Martin, T. J., Martinez, D., Martinez, J. L., Mercado, G., Mora, V., Mulhearn, M., Pena, J. L., Petty, R., Porch, W., Russell, C., Salas, R., Shannon, J. D., Shaw, W. J., Sosa, G., Tellier, L., Templeman, B., Watson, J. G., White, R., Whiteman, C. D., and Wolfe, D.: The IMADA-AVER boundary layer experiment in the Mexico City area, Bull. Am. Met. Soc., 79, 2497-2508, 1998.

Drewnick, F., Schwab, J. J., Jayne, J. T., Canagaratna, M. R., Worsnop, D. R., and Demerjian, K. L.: Measurement of ambient aerosol composition during the PMTACS-NY 2001 using an
Aerosol Mass Spectrometer. Part I: mass concentrations, Aerosol Sci. Technol., 38(S1), 92-103, 2004.

Dunlea E. J., Herndon, S. C., Nelson, D. D., Volkamer, R. M., Lamb, B. K,. Allwine, E. J., Grutter, M., Ramos Villegas, C. R., Marquez, C. , Blanco, S., Cardenas, B., Kolb, C. E., Molina, L. T., and Molina, M. J.: Technical note: Evaluation of Standard Ultraviolet Absorption Ozone Monitors in a Polluted Urban Environment, Atmos. Chem. Phys., 6, 3163-3180, 2006, http://www.atmos-chem-phys.net/6/3163/2006/.

Dunlea, E. J., Herndon, S. C., Nelson, D. D., Volkamer, R. M., San Martini, F., Sheehy, P. M., Zahniser, M. S., Shorter, J. H., Wormhoudt, J. C., Lamb, B. K., Allwine, E. J., Gaffney, J. S., Marley, N. A., Grutter, M., Marquez, C., Blanco, S., Cardenas, B., Retama, A., Ramos Villegas, C. R., Kolb, C. E., Molina, L. T., and Molina, M. J.: Evaluation of nitrogen dioxide chemiluminescence monitors in a polluted urban environment, Atmos. Chem. Phys. Discuss., 7, 569-604, 2007,

http://www.atmos-chem-phys-discuss.net/7/569/2007/.

Dunn, M. J., Jimenez, J. L., Baumgardner, D., Castro, T., McMurry, P. H., and Smith, J. N.: Measurements of Mexico City nanoparticle size distributions: Observations of new particle formation and growth, Geophys. Res. Lett., 31, L10102, doi:10.1029/2004GL019483, 2004.

Dzepina, K., Arey, J., Marr, L. C., Worsnop, D. R., Salcedo, D., Zhang, Q., Onasch, T. B., Molina, L. T., Molina, M. J., and Jimenez, J. L.: Detection of particle-phase polycyclic aromatic hydrocarbons in Mexico City using an Aerosol Mass Spectrometer, Int. J. Mass Spectrom., doi:10.1016/j.ijms.2007.01.010., 263, 152-170, 2007.

Edgerton, S. A., Arriaga, J. L., Archuleta, J., Bian, X., Bossert, J. E., Chow, J. C., Coulter, R. L., Doran, J. C., Doskey, P. V., Elliot, S., Fast, J. D., Gaffney, J. S., Guzman, F., Hubbe, J. M., Lee, J. T., Malone, E. L., Marley, N. A., McNair, L. A., Neff, W., Ortiz, E., Petty, R., Ruiz, M., Shaw, W. J., Sosa, G., Vega, E., Watson, J. G., Whiteman, C. D., and Zhong, S.: Particulate air pollution in Mexico City: A collaborative research project, J. Air Waste Manage. Assoc., 49, 1221-1229, 1999.

Evans, J., Levy, J., Hammitt, J., Santos-Burgoa, C., Castillejos, M., Caballero-Ramirez, M., Hernandez-Avila, M., RiojasRodriguez, H., Rojas-Bracho, L., Serrano-Trespalacios, P., Spengler, J. D., and Suh, H.: Health benefits of air pollution control, in: Air Quality in the Mexico Megacities: An Integrated Assessment, edited by: Molina, L. T. and Molina, M. J., Kluwer Academic Publishers, 103-136, 2002.

Fast, J. D. and Zhong, S. Y.: Meteorological factors associated with inhomogeneous ozone concentrations within the Mexico City basin, J. Geophys. Res., 103, 18 927-18 946, 1998.

Frey, S., Molina, L. T., Molina, M. J., and Wöste, L.: Design and implementation of a compact Raman-Lidar for ozone and aerosol measurements, European Space Agency (Special Publication) ESA SP, 1, 561, 151-154, 2004.

Gakenheimer, R., Molina, L. T., Sussman, J., Zegras, C., Howitt, A., Makler, J., Lacy, R., Slott, R., Villegas, A., Molina, M. J., and Sanchez, S.: The MCMA Transportation System: Mobility and Air Pollution, in: Air Quality in the Mexico Megacities: An Integrated Assessment, edited by: Molina, L. T. and Molina M. J., Kluwer Academic Publishers, 213-284, 2002.

Galle, B., Oppenheimer, C., Geyer, A., McGonigle, A. J. S., Edmonds, M., and Horrocks, L.: A miniaturised ultraviolet spec- 
trometer for remote sensing of $\mathrm{SO}_{2}$ fluxes: a new tool for volcano surveillance, J. Volcanol. Geotherm. Res., 119, 241-254, 2003.

Garcia, A. R., Volkamer, R., Molina, L. T., Molina, M. J., Samuelson, J., Mellqvist, J., Galle, B., Herndon, S. C., and Kolb, C. E.: Separation of emitted and photochemical formaldehyde in Mexico City using a statistical analysis and new pair of gas-phase tracers, Atmos. Chem. Phys., 6, 4545-4557, 2006, http://www.atmos-chem-phys.net/6/4545/2006/.

Grutter, M., Flores, E., Andraca-Ayala, G., and Baez, A.: Formaldehyde levels in downtown Mexico City during 2003, Atmos. Environ., 39, 1027-1034, 2005.

Hannigan, M. P., Cass, G. R., Penman, B. W., Crespi, C. L., Lafleur, A. L., Busby, W. F., Thilly, W. G., and Simoneit, B. R. T.: Bioassay directed chemical analysis of Los Angeles airborne particulate matter using a human cell mutagenicity assay, Environ. Sci. Technol., 22, 3502-3514, 1998.

Herndon, S. C., Jayne, J. T., Zahniser, M. S., Worsnop, D. R., Knighton, B., Alwine, E., Lamb, B. K., Zavala, M., Nelson, D. D., McManus, J. B., Shorter, J. H., Canagaratna, M. R., Onasch, T. B., and Kolb, C. E.: Characterization of urban pollutant emission fluxes and ambient concentration distributions using a mobile laboratory with rapid response instrumentation, Faraday Discuss., 130, 327-339, 2005.

Huffman, J. A., Jayne, J. T., Drewnick, F., Aiken, A. C., Onasch, T., Worsnop, D. R., and Jimenez, J. L.: Design, Modeling, Optimization, and Experimental Tests of a Particle Beam Width Probe for the Aerodyne Aerosol Mass Spectrometer, Aerosol Sci. Technol., 39(12), 1143-1163, doi:10.1080/02786820500423782, 2005.

Hughes, L. S., Allen, J. O., Bhave, P., Kleeman, M. J., Cass, G. R., Liu, D. Y., Fergenson, D. P., Morrical, B. D., and Prather, K. A.: Evolution of atmospheric particles along trajectories crossing the Los Angeles basin, Environ. Sci. Technol., 34(15), 3058-3068, 2000.

INE-SEMARNAT: Inventario Nacional de Emisiones de México, 1999, México D.F., 2006.

Jauregui, E.: Heat island development in Mexico City, Atmos. Environ., 31, 3821-3831, 1997.

Jayne, J. T., Leard, D. C., Zhang, X., Davidovits, P., Smith, K. A., Kolb, C. E., and Worsnop, D. R.: Development of an Aerosol Mass Spectrometer for size and composition analysis of sub- micron particles, Aerosol Sci. Technol., 33, 49-70, 2000.

Jazcilevich, A. D., Garcia, A. R., and Ruiz-Suarez, L. G.: A modeling study of air pollution modulation through land-use change in the Valley of Mexico, Atmos. Environ., 36, 2297-2307, 2002.

Jazcilevich, A. D., Garcia, A. R., and Ruiz-Suarez, L. G.: Locally induced surface air confluence by complex terrain and its effects on air pollution in the Valley of Mexico, Atmos. Environ., 39, 5481-5489, 2005.

Jiang, J., Marr, L. C., Dunlea, E. J., Herndon, S. C., Jayne, J. T., Kolb, C. E., Knighton, W. B., Rogers, T. M., Zavala, M., Molina, L. T., and Molina, M. J.: Vehicle fleet emissions of black carbon, polycyclic aromatic hydrocarbons, and other pollutants measured by a mobile laboratory in Mexico City, Atmos. Chem. Phys., 5, 3377-3387, 2005,

http://www.atmos-chem-phys.net/5/3377/2005/.

Johnson, K. S., Zuberi, B., Molina, L. T., Molina, M. J., Iedema, M. J., Cowin, J. P., Gaspar, D. J., Wang, C., and Laskin, A.:
Processing of soot in an urban environment: Case study from the Mexico City Metropolitan Area, Atmos. Chem. Phys., 5, 30333043, 2005,

http://www.atmos-chem-phys.net/5/3033/2005/.

Johnson, K. S., de Foy, B., Zuberi, B., Molina, L. T., Molina, M. J., Xie, Y., Laskin, A., and Shutthanandan, V.: Aerosol composition and source apportionment in the Mexico City Metropolitan Area with PIXE/PESA/STIM and multivariate analysis, Atmos. Chem. Phys., 6, 4591-4600, 2006,

http://www.atmos-chem-phys.net/6/4591/2006/.

Kolb, C. E., Herndon, S. C., McManus, J. B., Shorter, J. S., Zahniser, M. S., Nelson, D. D., Jayne, J. T., Canagaratna, M. R., and Worsnop, D. R.: Mobile laboratory with rapid response instruments for real-time measurements of urban and regional trace gas and particulate distributions and emission source characteristics, Environ. Sci. Technol., 38, 5694-5703, 2004.

Kulmala, M., Vehkamaki, H., Petajda, T., Dal Maso, M., Lauri, A., Kerminen, V. M., Birmili, W., and McMurry, P. H.: Formation and growth rates of ultrafine atmospheric particles: a review of observations, J. Aerosol Sci., 35(2), 143-176, 2004.

Kumar, R. and Joseph, A. E.: Air pollution concentrations of $\mathrm{PM}_{2.5}$, $\mathrm{PM}_{10}$, and $\mathrm{NO}_{2}$ at ambient and kerbside and their correlation in Metro City - Mumbai, Environmental Monitoring and Assessment, 119, 191-199, doi:10.1007/s10661-005-9022-7, 2006.

Laakso, L., Koponen, I. K., Monkkonen, P., Kulmala, M., Kerminen, V. M., Wehner, B., Wiedensohler, A., Wu, Z. J., and Hu, M.: Aerosol particles in the developing world: A comparison between New Delhi in India and Beijing in China, Water, Air, and Soil Pollution, 173, 1-4, 5-20, 2006.

Lei, W., de Foy, B., Zavala, M., Volkamer, R., and Molina, L. T.: Characterizing ozone production in the Mexico City Metropolitan Area: A case study using a chemical transport model, Atmos. Chem. Phys., 7, 1347-1366, 2007,

http://www.atmos-chem-phys.net/7/1347/2007/.

Lezama, J. L., Favela, R., Galindo, L. M., Ibarraran, M. E., Sanchez, S., Molina, L. T., Molina, M. J., and Connors, S. R., Fernandez-Bremauntz, A.: Forces driving pollutant emissions in the MCMA, in: Air Quality in the Mexico Megacity: An Integrated Assessment, edited by: Molina, L. T. and Molina, M. J., Kluwer Academic Publishers, Dordrecht, The Netherlands, 61104, 2002.

Marley, N. A., Gaffney, J. S., White, R. V., Rodriguez-Cuadra, L., Herndon, S. E., Dunlea, E., Volkamer, R. M., Molina, L. T., and Molina, M. J.: Fast gas chromatography with luminol chemiluminescence detection for the simultaneous determination of nitrogen dioxide and peroxyacetyl nitrate in the atmosphere, Rev. Sci. Instrum., 75, 4595-4605, 2004.

Marley, N. A., Gaffney, J. S., Ramos-Villegas, R., and Cardenas Gonzalez, B.: Comparison of measurements of peroxyacyl nitrates and primary carbonaceous aerosol concentrations in Mexico City determined in 1997 and 2003, Atmos. Chem. Phys., 7, 2277-2285, 2007a.

Marr, L. C., Grogan, L. A., Wöhrnschimmel, H., Molina, L. T., Molina, M. J., Smith, T. J., and Garshick, E.: Vehicle traffic as a source of particulate polycyclic aromatic hydrocarbon exposure in Mexico City, Environ. Sci. Technol., 38, 2584-2592, 2004.

Marr, L. C., Dzepina, K., Jimenez, J. L., Reisen, F., Bethel, H. L., Arey, J., Gaffney, J. S., Marley, N. A., Molina, L. T., and Molina, M. J.: Sources and transformations of particle-bound polycyclic 
aromatic hydrocarbons in Mexico City, Atmos. Chem. Phys., 6, 1733-1745, 2006,

http://www.atmos-chem-phys.net/6/1733/2006/.

Mayer, M., Wang, C., Webster, M., and Prinn, R. G.: Linking local air pollution to global chemistry and climate, J. Geophys. Res., 105, 22 869-22 896, 2000.

McMurry, P. H., Fink, M., Sakurai, H., Stolzenburg, M. R., Mauldin, R. L., III, Smith, J., Eisele, F., Moore, K., Sjostedt, S., Tanner, D., Huey, L. G., Nowak, J. B., Edgerton, E., and Voisin, D.: A criterion for new particle formation in the sulfurrich Atlanta atmosphere, J. Geophys. Res., 110(D22), D22S02, doi:2005006644, 2005.

Moya, M., Ansari, A., and Pandis, S.: Partitioning of nitrate and ammonium between the gas and particulate phases during the 1997 IMADA-AVER study in Mexico City, Atmos. Environ., 35, 1791-1804, 2001.

Molina, L. T. and Molina, M. J. (Eds.): Air Quality in the Mexico Megacity: An Integrated Assessment, Kluwer Academic Publishers, Dordrecht, The Netherlands, 2002.

Molina, M. J. and Molina, L. T., Megacities and Atmospheric Pollution, J. Air Waste Manage. Assoc., 54, 6, 644-680, 2004.

Molina, M. J., Molina, L. T., West, J., Sosa, G., Sheinbaum-Pardo, C., San-Martini, F., Angel-Zavala, M., and McRae, G.: Air pollution science in the MCMA: Understanding source-receptor relationships through emissions inventories, measurements, and modeling, in: Air Quality in the Mexico Megacity: An Integrated Assessment, edited by: Molina, L. T. and Molina, M. J., Kluwer Academic Publishers, Dordrecht, The Netherlands, 137202, 2002.

Molina, L. T., Molina, M. J., Slott, R., Kolb, C. E., Gbor, P. K., Meng, F., Singh, R., Galvez, O., Sloan, J. J., Anderson, W., Tang, X. Y., Shao, M., Zhu, T., Zhang, Y. H., Hu, M., Gurjar, B. R., Artaxo, P., Oyola, P., Gramsch, E., Hidalgo, P., and Gertler, A.: 2004 Critical Review Supplement: Air Quality in Selected Megacities, http://www.awma.org, 2004.

Mugica, V., Vega, E., Arriaga, J. L., Ruiz, and Ma, E.: Determination of motor vehicle profiles for non-methane organic compounds in the Mexico City Metropolitan Area, J. Air Waste Manage. Assoc., 48, 1060-1068, 1998.

Mugica, V., Vega, E., Chow, J., Reyes, E., Sanchez, G., Arriaga, J. L., Egami, R., and Watson, J.: Speciated non-methane organic compounds emissions from food cooking in Mexico, Atmos. Environ., 35, 1729-1734, 2001.

Mugica, V., Vega, E., Ruiz, H., Sanchez, G., Reyes, E., Cervantes, A.: Photochemical reactivity and sources of individual VOCs in Mexico City, in: Air pollution X, edited by: Brebbia, C. A. and Martin-Duque, J. F., WIT Press, UK, 2002.

Mugica, V., Ruiz, M. E., Watson, J., and Chow, J.: Volatile aromatic compounds in Mexico City atmosphere: levels and source apportionment, Atmosfera, 16, 15-27, 2003.

NARSTO: Improving emission inventories for effective air quality management across North America, NARSTO Inventory Assessment Team, NARSTO-05-001, 2005.

Onasch, T. B., Worsnop, D. R., Canagaratna, M., Jayne, J. T., Herndon, S., Mortimer, P., Kolb, C. E., Rogers, T., Knighton, B., Dunlea, E., Marr, L., de Foy, B., Molina, M., Molina, L., Salcedo, D., Dzepina, K., and Jimenez, J. L.: Variability of ambient aerosol in the Mexico City Metropolitan Area, Eos Tran. AGU, 85(47), Fall Meet. Suppl., Abstract A23D-01, 2004.
Pope III, A. C. and Dockery, D. W.: Critical Review: Health effects of fine particulate air pollution: lines that connect, J. Air Waste Manage. Assoc., 56, 709-742, 2006.

Reyes, F., Grutter, M., Jazcilevich, A., and Gonzalez-Oropeza, R.: Technical Note: Analysis of non-regulated vehicular emissions by extractive FTIR spectrometry: tests on a hybrid car in Mexico City, Atmos. Chem. Phys., 6, 5399-5346, 2006, http://www.atmos-chem-phys.net/6/5399/2006/.

Ristori, P., Simeonov, V., Taslakov, M., Molina, L., Molina, M., and van den Bergh, H.: Ozone and aerosol distribution measured above Mexico City with a differential absorption Lidar during the MCMA 2003 Field Campaign, in: Proceedings of the 22nd International Laser Radar Conference (ILRC), Matera, Italy, 812 July 2004, pp. 755-758, 2004.

Rogers, T. M., Grimsrud, E. P., Herndon, S. C., Jayne, J. T., Kolb, C. E., Allwine, E., Westberg, H., Lamb, B. K., Zavala, M., Molina, L. T., Molina, M. J., and Knighton, W. B.: On-road measurements of volatile organic compounds in the Mexico City Metropolitan Area using Proton Transfer Reaction Mass Spectrometry, Int. J. Mass Spectrom., 252, 26-37, 2006.

Rosas-Perez, I., Serrano, J., Alfaro-Moreno, E., Baumgardner, D., Garcia-Cuellar, C., Miranda-Martın del Campo, J., Raga, G. B., Castillejos, M., Drucker-Colin, R., and Osornio-Vargas, A.: Relations between $\mathrm{PM}_{10}$ composition and cell toxicity: A multivariate and graphical approach, Chemosphere, doi:10.1016/j.chemosphere.2006.10.078, 2006.

Salcedo, D., Onasch, T. B., Dzepina, K., Canagaratna, M. R., Zhang, Q., Huffman, J. A., DeCarlo, P. F., Jayne, J. T., Mortimer, P., Worsnop, D. R., Kolb, C. E., Johnson, K. S., Zuberi, B., Marr, L. C., Volkamer, R., Molina, L. T., Molina, M. J., Cardenas, B., Bernabe, R. M., Marquez, C., Gaffney, J. S., Marley, N. A., Laskin, A., Shutthanandan, V., Xie, Y., Brune, W., Lesher, R., Shirley, T., and Jimenez, J. L.: Characterization of ambient aerosols in Mexico City during the MCMA-2003 campaign with Aerosol Mass Spectrometry: results from the CENICA Supersite, Atmos. Chem. Phys., 6, 925-946, 2006,

http://www.atmos-chem-phys.net/6/925/2006/.

Salcedo, D., Onasch, T. B., Canagaratna, M. R., Dzepina, K., Huffman, J.A., Jayne, J. T., Worsnop, D. R., Kolb, C. E., Weimer, S., Drewnick, F., Allen, J. D., Della, A. E., and Jimenez, J. L.: Technical Note: Use of a beam width probe in an Aerosol Mass Spectrometer to monitor particle collection efficiency in the field, Atmos. Chem. Phys., 7, 549-556, 2007, http://www.atmos-chem-phys.net/7/549/2007/.

San Martini, F. M., West, J. J., Sosa, G., Molina, L. T., Molina, M. J., and McRae, G. J.: Modeling inorganic aerosols and their response to changes in precursor concentration in Mexico City, J. Air Waste Manage. Assoc., 55(6), 803-815, 2005.

San Martini, F. M., Dunlea, E. J., Grutter, M., Onasch, T. B., Jayne, J. T., Canagaratna, M. R., Worsnop, D. R., Kolb, C. E., Shorter, J. H., Herndon, S. C., Zahniser, M. S., Ortega, J. M., McRae, G. J., Molina, L. T., and Molina, M. J.: Implementation of a Markov Chain Monte Carlo method to inorganic aerosol modeling of observations from the MCMA-2003 Campaign. Part I: Model description and application to the La Merced site, Atmos. Chem. Phys., 6, 4867-4888, 2006a.

San Martini, F. M., Dunlea, E. J., Volkamer, R., Onasch, T. B., Jayne, J. T., Canagaratna, M. R., Worsnop, D. R., Kolb, C. E., Shorter, J. H., Herndon, S. C., Zahniser, M. S., Salcedo, 
D., Dzepina, K., Jimenez, J. L., Ortega, J. M., Johnson, K. S., McRae, G. J., Molina, L. T., and Molina, M. J.: Implementation of a Markov Chain Monte Carlo method to inorganic aerosol modeling of observations from the MCMA-2003 Campaign. Part II: Model application to the CENICA, Pedregal and Santa Ana sites, Atmos. Chem. Phys., 6, 4889-4904, 2006b.

Sardar, S. B., Fine, P. M., and Sioutas, C.: Seasonal and spatial variability of the size-resolved chemical composition of particulate matter $\left(\mathrm{PM}_{10}\right)$ in the Los Angeles basin, J. Geophys. Res.Atmos., 110, D07S08, doi:10.1029/2004JD004627, 2005.

Schifter, I., Diaz, L, Lopez-Salinas, E., Ramos, F., Avalos, S., Lopez-Vidal, G., and Castillo, M.: Estimation of motor vehicle toxic emissions in the Metropolitan Area of Mexico City, Environ. Sci. Technol., 34, 3606-3610, 2000.

Schifter, I., Diaz, L., Duran, J., Guzman, E., Chavez, O., and LopezSalinas, E.: Remote sensing study of emissions from motor vehicles in the Metropolitan Area of Mexico City, Environ. Sci. Technol., 37, 395-401, 2003.

Schifter, I., Diaz, L., Mugica, V., and Lopez-Salinas, E.: Fuel-based motor vehicle emission inventory for the metropolitan area of Mexico City, Atmos. Environ., 39, 931-940, 2005.

Shirley, T. R., Brune, W. H., Ren, X., Mao, J., Lesher, R., Cardenas, B., Volkamer, R., Molina, L. T., Molina, M. J., Lamb, B. , Velasco, E., Jobson, T., and Alexander, M.: Atmospheric oxidation in the Mexico City Metropolitan Area (MCMA) during April 2003, Atmos. Chem. Phys., 6, 2753-2765, 2006, http://www.atmos-chem-phys.net/6/2753/2006/.

Simeonov, V., Ristori, P., Taslakov, M., van den Bergh, H., Molina, L. T., and Molina, M. J.: Ozone and aerosol distribution measured above Mexico City with a differential absorption Lidar during the MCMA 2003 Field Campaign, in: Proceedings of the XX Quadrennial Ozone Symposium, Kos Greece, 1-8 June 2004, 1, 435-437, 2004.

Streit, G. E. and Guzman, F.: Mexico City air quality: Progress of an international collaborative project to define air quality management options, Atmos. Environ., 20, 723-733, 1996.

Tie, X., Madronich, S., Li, G. H., Ying, Z., Zhang, R., Garcia, A. R., Lee-Taylor, J., and Liu, Y.: Characterizations of chemical oxidants in Mexico City: A regional chemical dynamical model (WRF-Chem) study, Atmos. Environ., 41, 1989-2008, 2007.

Ulbrich, I. M., Zhang, Q., Salcedo, D., Dzepina, K., Canagaratna, M. R., Worsnop, D. R., and Jimenez, J. L.: Source apportionment of Aerosol Mass Spectrometer data in Pittsburgh, Mexico City, and Houston by positive matrix factorization, Eos Trans. AGU, 87(52), Fall Meet. Suppl., Abstract A23C-0980, 2006.

Vega, E., Mugica, M., Carmona, R., and Valencia, E.: Hydrocarbon source apportionment in Mexico City using the chemical mass balance receptor model, Atmos. Environ., 34, 4121-4129, 2000.

Vega, E., Mugica, V., Reyes, E., Sanchez, G., Chow, J. C., and Watson, J. G.: Chemical composition of fugitive dust emitters in Mexico City, Atmos. Environ., 35, 4033-4039, 2001.

Velasco, E.: Estimates for biogenic non-methane hydrocarbons and nitric oxide emissions in the Valley of Mexico, Atmos. Environ., 37, 625-637, 2003.

Velasco, E., Pressley, S., Allwine, E., Westberg, H., and Lamb, B.: Measurements of $\mathrm{CO}_{2}$ fluxes from the Mexico City urban landscape, Atmos. Environ., 39, 7433-7466. 2005a.

Velasco, E., Lamb, B., Pressley, S., Allwine, E., Westberg, H., Jobson, T., Alexander, M., Prazeller, P., Molina, L., and
Molina, M.: Flux measurements of volatile organic compounds from an urban landscape, Geophys. Res. Lett., 32, L20802, doi:10.1029/2005GL023356, 2005b.

Velasco, E., Lamb, B., Westberg, H., Allwine, E., Sosa, G., Arriaga-Colina, J. L., Jobson, B. T., Alexander, M., Prazeller, P., Knighton, W. K., Rogers, T. M., Grutter, M., Herndon, S. C., Kolb, C. E., Zavala, M., de Foy, B., Volkamer, R., Molina, L. T., and Molina, M. J.: Distribution, magnitudes, reactivities, ratios and diurnal patterns of volatile organic compounds in the Valley of Mexico during the MCMA 2002 and 2003 Field Campaigns, Atmos. Chem. Phys., 7, 329-353, 2007, http://www.atmos-chem-phys.net/7/329/2007/.

Volkamer, R., Molina, L. T., Molina, M. J., Flores, E., Grutter, M., Galle, B., Mellqvist, J., Samuelson, J., Knighton, B., and Jobson, B. T.: Open-path emission factors derived from DOAS and FTIR measurements in the Mexico City Metropolitan Area, in: Air Pollution as a Climate Forcing: A Second Workshop, 61396152, 2005a.

Volkamer, R., Molina, L. T., Molina, M. J., Shirley, T., and Brune, W. H.: DOAS measurement of glyoxal as an indicator for fast VOC chemistry in urban air, Geophys. Res. Lett., 32, L08806, doi:10.1029/2005GL022616, 2005b.

Volkamer, R., Jimenez, J. L,. San Martini, F., Dzepina, K., Zhang, Q., Salcedo, D., Molina, L. T., Worsnop, D. R., and Molina, M. J.: Secondary organic aerosol formation from anthropogenic air pollution: rapid and higher than expected, Geophys. Res. Lett., 33, L17811, doi:10.1029/2006GL026899, 2006.

Volkamer, R., Sheehy, P. M., Molina, L. T., and Molina, M. J.: Oxidative capacity of the Mexico City atmosphere - Part 1: A radical source perspective, Atmos. Chem. Phys. Discuss., 7, 53655412, 2007, http://www.atmos-chem-phys-discuss.net/7/5365/2007/.

West, J. J., Zavala, M. A., Molina, L. T., Molina, M. J., San Martini, F., McRae, G. J., Sosa-Iglesias, G., and Arriaga-Colina, J. L.: Modeling ozone photochemistry and evaluation of hydrocarbon emissions in the Mexico City metropolitan area, J. Geophys. Res., 109, D19312, doi:10.1029/2004JD004614, 2004.

Wöhrnschimmel, H., Marquez, C., Mugica, V., Stahle, W. A., Staehelin, J., Cardenas, B., and Blanco, S.: Vertical profiles and receptor modeling of volatile organic compounds over Southeastern Mexico City, Atmos. Environ., 40, 5125-5136, 2006.

Zavala, M., Herndon, S. C., Slott, R. S., Dunlea, E. J., Marr, L. C., Shorter, J. H., Zahniser, M., Knighton, W. B., Rogers, T. M., Kolb, C. E., Molina, L. T., and Molina, M. J.: Characterization of on-road vehicle emissions in the Mexico City Metropolitan Area using a mobile laboratory in chase and fleet average measurement modes during the MCMA-2003 Field Campaign, Atmos. Chem. Phys., 6, 5129-5142, 2006, http://www.atmos-chem-phys.net/6/5129/2006/.

Zhang, Q., Stanier, C. O., Canagaratna, M. R., Jayne, J. T., Worsnop, D. R., Pandis, S. N., and Jimenez, J. L.: Insights into the chemistry of new particle formation and growth events in Pittsburgh based on Aerosol Mass Spectrometry, Environ. Sci. Technol., 38, 4797-4809, 2004.

Zhang, Q., Canagaratna, M. R., Jayne, J. T., Worsnop, D. R., and Jimenez, J. L.: Time and size-resolved chemical composition of submicron particles in Pittsburgh - Implications for aerosol sources and processes, J. Geophys. Res.-Atmos., 110, D07S09, doi:10.1029/2004JD004649, 2005a. 
Zhang, Q., Alfarra, M. R., Worsnop, D. R., Allan, J. D., Coe, H., Canagaratna, M. R., and Jimenez, J. L.: Deconvolution and quantification of hydrocarbon-like and oxygenated organic aerosols based on Aerosol Mass Spectrometry, Environ. Sci. Technol., 39, 4938-4952, 2005b.
Zhang, Q., Worsnop, D. R., Canagaratna, M. R., and Jimenez, J. L.: Hydrocarbon-like and oxygenated organic aerosols in Pittsburgh: Insights into sources and processes of organic aerosols, Atmos. Chem. Phys., 5, 3289-3311, 2005c. 